NBER WORKING PAPER SERIES

\title{
DOES TELEVISION ROT YOUR BRAIN? NEW EVIDENCE FROM THE COLEMAN STUDY
}

\author{
Matthew Gentzkow \\ Jesse M. Shapiro \\ Working Paper 12021 \\ http://www.nber.org/papers/w12021
NATIONAL BUREAU OF ECONOMIC RESEARCH
1050 Massachusetts Avenue
Cambridge, MA 02138
February 2006

\begin{abstract}
We are grateful to Dominic Brewer, John Collins, Ronald Ehrenberg, Eric Hanushek, and Mary Morris (at ICPSR) for assistance with Coleman study data, and to Christopher Berry for supplying data on school quality. Lisa Furchtgott and Jennifer Paniza provided outstanding research assistance. We thank Marianne Bertrand, Ed Glaeser, Austan Goolsbee, Caroline Hoxby, Larry Katz, Steve Levitt, Ethan Lieber, Kevin M. Murphy, Emily Oster, Andrei Shleifer, Chad Syverson, Bob Topel, and workshop participants at the University of Chicago and Harvard University for helpful comments. The views expressed herein are those of the author(s) and do not necessarily reflect the views of the National Bureau of Economic Research.

(C2006 by Matthew Gentzkow and Jesse M. Shapiro. All rights reserved. Short sections of text, not to exceed two paragraphs, may be quoted without explicit permission provided that full credit, including (C) notice, is given to the source.
\end{abstract}


Does Television Rot Your Brain? New Evidence from the Coleman Study

Matthew Gentzkow and Jesse M. Shapiro

NBER Working Paper No. 12021

February 2006

JEL No. I21, J13, J24

\begin{abstract}
We use heterogeneity in the timing of television's introduction to different local markets to identify the effect of preschool television exposure on standardized test scores later in life. Our preferred point estimate indicates that an additional year of preschool television exposure raises average test scores by about .02 standard deviations. We are able to reject negative effects larger than about .03 standard deviations per year of television exposure. For reading and general knowledge scores, the positive effects we find are marginally statistically significant, and these effects are largest for children from households where English is not the primary language, for children whose mothers have less than a high school education, and for non-white children. To capture more general effects on human capital, we also study the effect of childhood television exposure on school completion and subsequent labor market earnings, and again find no evidence of a negative effect.
\end{abstract}

\author{
Matthew Gentzkow \\ University of Chicago \\ 5807 S. Woodlawn Avenue \\ Chicago, IL 60637 \\ gentzkow@chicagogsb.edu \\ Jesse M. Shapiro \\ University of Chicago \\ 5807 S. Woodlawn Avenue \\ Chicago, IL 60637 \\ and NBER \\ jmshapir@uchicago.edu
}




\section{Introduction}

Television has attracted young viewers since broadcasting began in the 1940s. Concerns about the effects of television on young children emerged almost immediately, and have been fueled by a steady stream of academic research showing a negative association between television viewing and student achievement. ${ }^{1}$ These findings have made the introduction and diffusion of television a popular explanation for trends such as the decline in average verbal SAT scores during the 1970s (Wirtz et al, 1977; Winn, 2002), and the secular decline in verbal ability across cohorts (Glenn, 1994). They have contributed to a widespread belief among pediatricians that television is detrimental to cognitive development and academic achievement (Gentile et al, 2004), and have provided partial motivation for recent recommendations that young children's television viewing time be severely restricted (American Academy of Pediatrics, 2001). Given the important role that cognitive skills play in individual (Griliches and Mason, 1972) and aggregate (Bishop, 1989) labor market performance, understanding the cognitive effects of television viewing may have significant implications for public policy and household behavior.

In this paper, we identify the effect of childhood exposure to television on cognitive development by exploiting variation in the year of introduction of television to U.S. cities (Gentzkow, 2006). Television was introduced to most U.S. cities in the late 1940s and early 1950s, and was adopted rapidly, especially by families with children. Additionally, survey evidence suggests that young children who had television in their homes during this period watched as much as three hours of television per day, considerably more than the time spent listening to the radio for analogous ages in the 1930s. Finally, evidence from surveys of television ownership suggest that the diffusion of television was broad-based, reaching families in many different socioeconomic strata. These facts make the introduction of television in the United States a unique laboratory in which to study the effects of television on children.

To conduct our analysis, we use data from the Coleman study on the test scores of over 300,000

\footnotetext{
${ }^{1}$ Recent studies showing negative cross-sectional correlations betweeen measured television viewing and academic performance include Vandewater et al. (2005) and Borzekowski and Robinson (2005). Recent studies showing negative correlations between early childhood viewing and later performance include Zimmerman and Christakis (2005), Hancox, Milne, and Poulton (2005), and Christakis et al. (2004). Zavodny (2006) shows that the apparent negative effect of television disappears in a panel regression with individual fixed effects. An older literature finds more mixed results, but reviewers conclude that the overall thrust of the evidence points toward negative effects of television (Strasburger 1986; Beentjees \& Van der Voort 1988; Van Evra 1998).
} 
students ages 11, 14, and 17 (grades 6, 9, and 12) in 1965. These students were born during the period 1948-1954, just as television was expanding throughout the United States. Since television entered different U.S. markets at different times, different students were exposed to different amounts of television as preschoolers. Students in our sample therefore range from those who had television in their local area throughout their lives (for example, 6th graders whose areas got television between 1945 and 1951) to those whose areas only began receiving broadcasts after they reached age 6 (12th graders whose areas got television in 1954). Because the Coleman sample includes students of different ages within the same television market, we can identify the effects of television by comparing across cohorts within a given area. This differences-in-differences approach allows us to estimate the effect of television while holding constant fixed characteristics of a locale that affect test scores and might also be correlated with the timing of television introduction.

We find strong evidence against the prevailing wisdom that childhood television viewing causes harm to cognitive or educational development. Our preferred point estimate indicates that an additional year of preschool television exposure raises average test scores by about .02 standard deviations. We are able to reject negative effects larger than about .03 standard deviations per year of television exposure. For reading and general knowledge scores - domains where intuition and existing evidence suggest that learning from television could be important — we find marginally statistically significant positive effects.

A number of specification checks support the identification assumption that the timing of television's entry into different markets is uncorrelated with direct determinants of test scores. Most importantly, controlling for area fixed effects, we find that a student's childhood exposure to television is orthogonal to his or her predetermined demographic characteristics. That is, the within-area, cross-cohort variation in television exposure that identifies our models does not correlate with demographic variables that would be expected to affect test scores. We also find that the timing of television introduction was uncorrelated with trends in area school quality, income, and population density. Thus, although by definition we cannot test that our key exposure measures are orthogonal to unobservable variation in student ability, we do show that these measures are unrelated to many observable covariates of exam performance.

After establishing our results on the average effects of television, we turn to an analysis of 
heterogeneity in the effects of television on test scores. The positive effects we find on verbal, reading, and general knowledge tests are largest for children from households where English is not the primary language, for children whose mothers have less than a high school education, and for non-white children. These findings seem most consistent with a model in which the cognitive effects of television exposure depend on the educational value of the alternative activities that television crowds out.

We also find evidence that families in which television has relatively positive effects on learning allocate more time to viewing, which seems consistent with a rational-choice model in which parents choose to allow more television viewing in households where television viewing is likely to result in greater cognitive gains. In this respect, our paper relates to the literature on empirical selection into behaviors (Roy, 1951; Heckman and Sedlacek, 1985; Heckman, 1996).

Because television may also have important non-cognitive effects, we also estimate the effects of television on behavioral and attitudinal outcomes such as time spent on homework and desired school completion. Additionally, in light of recent evidence (see, e.g., Heckman and Rubinstein, 2001) that non-cognitive skills are valued in the labor market, we test for an impact of childhood television exposure on subsequent labor market outcomes. Although our estimates for both of these categories are less precise than the test score measures, we again find no evidence of a negative effect of television.

In addition to its obvious relationship with the large literature on the cognitive effects of television, this paper contributes to a growing economic literature on the effects of mass media on political and economic behavior (see, e.g., Djankov, McLiesh, Nenova and Shleifer, 2003; Gentzkow and Shapiro, 2004 and 2006; Gentzkow 2006; Stromberg, 2004; DellaVigna and Kaplan, 2005). Although our identification is driven by historical market-level changes and not by contemporary parental decision-making, our estimates may also inform debates on the effects of parental behaviors on children's skill acquisition (e.g., Levitt and Dubner 2005).

The remainder of the paper is organized as follows. Section 2 discusses the history of the introduction and diffusion of television and describes our procedure for collecting data on the timing of television entry to U.S. markets. Section 3 presents our data, identification strategy, and results. Section 4 presents an analysis of heterogeneity across students in the cognitive effects of 
television. Section 5 shows evidence on the effects of television on non-cognitive skills and labor market outcomes. Section 6 concludes.

\section{The Introduction and Diffusion of Television}

\subsection{The Growth of Commercial Broadcasting}

Although television did not achieve rapid growth until after World War II, the basic technology was already well developed by the late 1930s. The first workable prototypes for television receivers were made in the early 1920s, the first public demonstration took place in 1923, and numerous experimental broadcasts were made in the late 1920s. By 1931, 18 experimental stations were operating in four cities. The first television sets went on sale in 1938 and by 193914 companies were offering sets for sale. ${ }^{2}$ After several delays, the Federal Communications Commission (FCC) finally licensed television for full-scale commercial broadcasting on July 1, 1941.

Two unexpected events intervened to delay television's expansion. The first was World War II: less than a year after the FCC authorization, the government issued a ban on new television station construction to preserve materials for the war effort. Although existing stations continued to broadcast, the total number of sets in use during the war was less than 20,000. After the war, television grew rapidly. Over 100 new licenses were issued between 1946 and 1948, so that by 1950 half of the country's population was reached by television signals. ${ }^{3}$ This growth was again halted, however, by an FCC-imposed freeze on new television licenses in September 1948. The FCC had determined that spectrum allocations did not leave sufficient space between adjacent markets, causing excessive interference. The process of redesigning the spectrum allocation took four years, and it was not until April 1952 that the freeze was lifted and new licenses began to be issued.

We can look at the pattern of television's growth in a number of different ways. Figure 1 shows the time path of diffusion. In the largest counties, twenty percent had televisions by 1950, and 80 percent had televisions by 1955. Figure 2 shows the number of commercial stations broadcasting: the post-war expansion, freeze, and subsequent takeoff are clearly visible. Finally, as figure 3

\footnotetext{
${ }^{2}$ This section draws primarily on Sterling and Kittross (2001) and Barnouw (1990). For details on the regulatory process, see also Slotten (2000).

${ }^{3}$ We consider a county to be reached by television if it is in a Nielsen Designated Market Area that had at least one station by 1950 .
} 
suggests, television penetration was not limited to the highly educated. Television penetration rose from 8 percent to 82 percent from 1949 to 1955 among those with high school degrees, and from 4 percent to 66 percent among those without. Other demographic groups tend to show a similar pattern: television diffusion was rapid among both whites and non-whites, and among both elderly and non-elderly Americans.

The rapid diffusion of television was accompanied by extremely high rates of viewership among television households. In households with television, viewership had already surpassed four and a half hours per day by 1950 (Television Bureau of Advertising 2003). Critically for our study, children were among the most enthusiastic early viewers of television. Programs targeted specifically at children were introduced early, with Howdy Doody making its debut in 1947 and a number of popular series like Kukla and Ollie, Jamboree Room, and Children's Matinee on the air by 1948 (Television January 1948). As early as 1951 there was programming targeted specifically at preschool children (Barnouw 1990, p. 146). In fact, children's programs accounted for more time on network television than any other category in 1950 (Roslow, 1952), and by 1951 advertisers were spending $\$ 400,000$ per week to reach the children's market (Television August 1951). Furthermore, children were frequent viewers of programming primarily targeted at adults - to take one example, I Love Lucy was ranked the most favored program among elementary-school students in 1952, 1953, and 1954 surveys (Television April 1955). ${ }^{4}$

There were no large-scale studies of children's viewing hours in the 1950s, but a series of small surveys make clear that intense viewing was common from television's earliest years. Median daily viewership in samples of elementary-school children ranged from 2.0 hours per day to 3.7 hours per day, with the earliest studies showing 3.1 hours per day in 1948 (ages 6-12), 3.7 hours per day in 1950-51 (grades 6-7), 2.7 hours per day in 1951 (elementary ages), 3.3 hours in 1953 (elementary ages), 3.7 hours in 1954 (grades 4-8), and 3.4 hours in 1955 (elementary ages). ${ }^{5}$ Direct evidence on viewing by preschool children in this period is limited, but one survey of families in San Francisco in 1958 found that weekday viewing averaged 0.7 hours per day for 3-year-olds, 1.6 hours per day for 4-year-olds, and 2.3 hours per day for 5-year-olds, with weekend viewing on average half an

\footnotetext{
${ }^{4}$ A 1960 study found that 40 percent of children's viewing was devoted to adult programs (Schramm, Lyle, and Parker 1961, 41).

${ }^{5}$ See Schramm, Lyle, and Parker (1961) for a review of this evidence.
} 
hour to an hour higher (Schramm, Lyle, and Parker, 1961).

Finally, two studies from the period suggest that television brought dramatic changes to the way children allocated their time. First, Maccoby (1951) surveyed 622 children in Boston in 1950 and 1951 and matched children with and without television by age, sex, and socioeconomic status. The study found that radio listening, movie watching, and reading were substantially lower in the television group, but also that total media time was greater by approximately an hour and a half per day. ${ }^{6}$ The television group went to bed almost half an hour later, spent less time on homework, and spent more than an hour less time in active play. The second study, conducted in 1959, surveyed children in two similar towns in Western Canada of which only one had television available (Schramm, Lyle, and Parker 1961, 18). First-grade children in the town with television watched for an average of an hour and 40 minutes per day. They spent 35 fewer minutes listening to radio, 33 fewer minutes at play, 13 fewer minutes sleeping, and 20 fewer minutes reading and watching movies. Sixth grade children showed similar shifts in time allocation and also spent 15 fewer minutes on homework.

\subsection{Television Penetration in Local Markets}

Our estimation strategy relies on information about the availability of television in U.S. cities beginning in 1946. We use data from Gentzkow (2006) on the year in which the first television station appeared in a given market. We define television markets using the Designated Market Area (DMA) concept designed by Nielsen Media Research (NMR). NMR assign every county in the US to a television market such that all counties in a given market have a majority of their measured viewing hours on stations broadcasting from that market. These definitions are based on viewership as of 2003, rather than in the historical period we are analyzing. However, since the broadcasting strength of stations is regulated by the FCC to avoid interference with neighboring markets, the area reached by particular stations has not changed significantly. ${ }^{7}$ We therefore take the DMA definitions as a reasonable approximation of the viewing area of stations in the 1950s and

\footnotetext{
${ }^{6}$ The observation that the time devoted to television did not simply replace radio is also supported by a number of studies suggesting that even in the 1930s radio listening averaged little more than an hour per day (Fox Meadow School PTA 1933; Eisenberg 1936).

${ }^{7}$ This has been verified by spot-checking the DMA definitions against coverage maps from the 1960s.
} 
$60 \mathrm{~s}$, and calculate the first year in which a station in the DMA broadcast for at least four months. ${ }^{8}$

An examination of historical records suggests two potential sources of endogeneity in the timing of television's introduction to a market. First, the FCC prioritized applications for new stations in such a way as to maximize the number of Americans who could receive a commercial television signal. Conditional on the quality of existing coverage in a market, the FCC therefore handled applications to begin broadcasting in order of the market's total population (Television Digest 1953). Second, since a station's profitability was determined largely by advertising revenue, which in turn depends on the spending power of the market's population, commercial interest in operating stations in a given market was highly related to the market's total retail sales or income. In all of the specifications we report below, we include controls for the natural logarithm of total DMA population and income as measured in the 1960 Census. As table 1 shows, the variation in the timing of television introduction left over after controlling for income and population appears to be largely idiosyncratic. Although our identification strategy will rely only on changes across cohorts within a given market, rather than differences across markets, including these controls (interacted with cohort dummies) will limit the chance that our results will be confounded by unobserved differences in cohort or time trends across markets of different size or wealth.

To illustrate the impact of broadcast availability on television ownership, figure 4 shows television penetration for DMAs by year of television's introduction for 1950 using Census data. The height of each bar is the fraction of households with televisions in all counties that received television in the given year. The data reveal a clear distinction between counties that had a television station in their DMA and those that did not - the average penetration in DMAs whose first station began broadcasting before 1950 ranges from 8 percent in the 1949 group to over 35 percent in the 1941 group, while the average for groups getting television after 1950 never exceeds 1 percent. This suggests that the timing of commercial television introduction had a substantial impact on actual penetration, a fact that will be crucial to our estimation strategy.

\footnotetext{
${ }^{8}$ In most cases, we use the date that a station began commercial broadcasts, as regulated by the FCC. The exceptions are two stations-KTLA in Los Angeles and WTTG in Washington, DC - that began large-scale experimental broadcasts and subsequently converted to become commercial stations. In these cases, we use the stations' experimental start dates.
} 


\section{Estimates of the Effects of Television on Cognitive Development}

\subsection{Data: The Coleman Study}

Our data on test scores will come from the 1966 study Equality of Educational Opportunity, often informally called the Coleman Report. ${ }^{9}$ The study includes data on 567,148 students who were in grades $1,3,6,9$, or 12 in 1965. Sampling was conducted through the construction of primary sampling units (PSUs) consisting of either counties or metropolitan areas. Because racial equality was a primary focus of the study, nonwhite students were oversampled.

The surveyors first chose schools with twelfth grades. Then, for each school containing a twelfth grade, they made an effort to identify the middle and elementary schools that "fed" their students into the secondary school. Therefore for each student in the sample, the dataset identifies the school the student is most likely to attend as a twelfth-grader. It is this variable we will employ when we estimate specifications with "school" fixed effects.

Each student completed a survey and an exam, both of which were administered in the fall of 1965. We will focus our analysis on sixth, ninth, and twelfth graders because these students' birth cohorts (1948-1954) span most of the period during which television was introduced, and because exam style and format were fairly similar across these different grades. Exams for sixth, ninth and twelfth graders contained sections on word meaning, spatial reasoning, reading, and mathematics; ninth and twelfth graders completed an additional section on general knowledge. In addition to information on test scores, we extracted data on demographic characteristics from the student surveys. We tried to include all characteristics that were available and reasonably comparable across all three grades.

\subsection{Difficulties with Correlational Evidence}

To consider how correlational estimates of television's effect might be biased, table 2 presents regressions of both average test scores and self-reported hours of (contemporaneous) television viewing on demographics. The first half of the table shows coefficients on family background variables, such as race and education. In almost all of these cases, the effects of these demographic characteristics

\footnotetext{
${ }^{9}$ For examples of other studies by economists using data from this study, see Hanushek and Kain (1972) and Ehrenberg and Brewer (1995).
} 
on television hours are statistically significant and in the opposite direction from their effects on average test scores. Therefore, we would expect any unobserved variation in these characteristics to tend to bias an OLS regression of test scores on television viewing towards finding negative effects of television. The second half of the table shows that measures of durables ownership - a proxy for family income or wealth - tend to have positive effects on both television viewing and test scores, controlling for family background. This finding is not surprising since these proxies for wealth are highly correlated with television ownership, and are probably also highly related to the quality of the television set available in the household. So an OLS regression of test scores on television viewing that did not control carefully for family income might find that television has a positive effect on student performance. This type of bias seems especially likely in contexts where television ownership is not universal or where quality of sets or programming is likely to be highly variable with income.

These estimates suggest that OLS regressions of test scores on television viewership can easily be subject to upward or downward bias, depending on which household characteristics are measured well and which are measured poorly by the econometrician. To show this more explicitly, table 3 presents correlational estimates of the effect of television viewing on average test scores, using alternative sets of controls. As predicted, when we control for family background measures such as race and education, but not for our wealth proxies, we find an average effect of television viewing that is positive and highly statistically significant. In contrast, when we include wealth proxies but not family background controls, the estimated effect becomes large, statistically significant, and negative. Similar results are present when comparing effects on component test scores under alternative sets of controls. Effects are in general more positive (or less negative) when we control for family background and omit wealth controls than when we do the reverse. Indeed, for verbal and reading scores we again see a strong sign reversal.

We believe this finding may help to explain why correlational studies of the effects of television reach highly variable conclusions (Strasburger 1986). Since these studies are only as good as the controls they employ, and since table 3 shows that omitted variables problems could lead either to an upward or downward bias of the effects of television, it is not surprising that different academic studies employing different econometric specifications reach radically different conclusions. In a 
study that controls carefully for family background but not for income, we would expect to find positive effects of television. By contrast, controlling carefully for income or wealth but not for parental education and other background characteristics will lead to a downward bias and findings of deleterious effects of television.

\subsection{Identification Strategy}

To illustrate how we will identify the effects of television in our data, suppose that childhood exposure to television has a negative effect on test scores. Consider two cities, one in which television was introduced in 1948, the other in which it was introduced in 1951. In the first city, sixth, ninth, and twelfth graders were all exposed to television throughout childhood. In the second, sixth and ninth graders had lifetime exposure to television, but twelfth graders only got television at age 3 . We would expect twelfth graders in the second city to perform well relative to sixth and ninth graders in that city, but we would expect no such pattern in the first city. By differencing out the mean test scores by grade from the first city, we can hope to isolate the effects of television using grade patterns in the second city.

We will implement this identification strategy using a two-stage least squares (2SLS) procedure, in which dummies for the year of television introduction interacted with grade are used as instruments for the number of preschool years in which a student's household had television. Letting years $s_{i}$ denote the number of years of preschool television exposure for student $i$, we can estimate the following model of test scores $y_{i}$ :

$$
\begin{aligned}
y_{i} & =\psi\left(\text { years }_{i}\right)+X_{i} \beta+\delta_{g}+W_{c} \gamma_{g}+\mu_{s}+\varepsilon_{i} \\
\text { years }_{i} & =Z_{g c} \alpha+X_{i} \beta^{0}+\delta_{g}^{0}+W_{c} \gamma_{g}^{0}+\mu_{s}^{0}+\varepsilon_{i}^{0}
\end{aligned}
$$

where $Z_{g c}$ is a vector of dummies for interactions between the television introduction year of city $c$ and the grade $g$ of the student, $X_{i}$ is a vector of individual-level demographic characteristics, $W_{c}$ is a vector of DMA characteristics (log of income and population), $\delta_{g}$ are grade dummies, and $\mu_{s}$ are school dummies. By allowing the error $\varepsilon_{i}$ to be correlated across students within the same DMA, we can correct our standard errors for the fact that variation in $Z_{g c}$ is at the DMA level, as well as 
for the presence of DMA-specific shocks that are common across grades (Moulton, 1990; Bertrand, Duflo and Mullainathan, 2004).

The crucial identifying assumption in this model is that, conditional on school dummies $\left(\mu_{s}\right)$ and grade dummies $\left(\delta_{g}\right)$ and on the interaction between grade dummies and DMA-level characteristics $\left(W_{c} \gamma_{g}\right)$, the interaction between the timing of television introduction and the birth cohort of the student $\left(Z_{g c}\right)$ is orthogonal to the error term $\left(\varepsilon_{i}\right)$. Under this assumption, our estimate of the parameter $\psi$ will be directly interpretable as an estimate of the causal effect of an additional year of preschool television exposure on test scores $y_{i}$.

One practical difficulty with implementing model (1) is that the Coleman Study's questionnaire did not ask students when their households first owned a television. We therefore cannot use individual-level data on the television exposure variable year $s_{i}$ to estimate the model. To circumvent this problem, we have constructed a predicted value of year $s_{i}$ using a new dataset of television penetration statistics by U.S. county for the years 1950-1960. The 1950 and 1960 U.S. Censuses included a question on television ownership, so for those years we simply use the share of households owning a television as reported by the Census. For intercensal years, our primary source is Television magazine, which used Census data as well as published reports by the Advertising Research Foundation, A.C. Nielsen, NBC, and CBS, as well as television shipments data, to construct annual estimates of penetration by county. We use data from Television for the years 1954-1959 and from the Television Factbook for $1953 .^{10}$ For years with missing data, we used a linear interpolation (or extrapolation) from the surrounding years, with a transformation that restricts penetration shares to fall between 0 and $1 .^{11}$

To predict total years of television exposure for each student in the dataset, we assume that the probability that a student's household had television in a given year is equal to the share of households in the student's 1965 county of residence who had television sets in that year. ${ }^{12}$ By

\footnotetext{
${ }^{10}$ The correlation between Television's county-level penetration estimates for 1959 and the U.S. Census counts for 1960 is a highly statistically significant $0.64(p<0.0001)$. Given that Television did not yet have access to the Census reports when producing these figures, this correlation suggests reasonably high reliability.

${ }^{11}$ In particular, we computed the transformation log (penetration/ $(1$ - penetration $)$ ) and imputed missing values using a linear interpolation (or extrapolation) of this transformed measure. We then used the inverse function to re-transform the imputed values to a $0-1$ scale. This approach amounts to assuming that television diffusion follows an S-shaped logistic process in years with missing data (Griliches, 1957).

${ }^{12}$ When the Coleman data do not provide information on a student's county of residence, we use the student's Standard Metropolitan Statistical Area of residence in 1965 to estimate television ownership.
} 
summing these probabilities, we can obtain an approximation of the student's number of years of preschool television exposure during ages two through six. For example, consider a student born in 1948, and therefore in grade 12 in 1965. Suppose that in 1950 (age two), 10 percent of households in the student's county had television, and that 11 percent had it in 1951, 12 percent in 1952, 13 percent in 1953, and 14 percent in 1954 (age six). Then we calculate the student's expected years of preschool television exposure as $(0.10+0.11+0.12+0.13+0.14)=0.6$. We have chosen to ignore ages below two because there is relatively less information about viewing patterns in those ages, so we can have comparatively less confidence that children in these ages were actually watching television in the 1950s. We restrict attention to ages six and below because by age six, essentially every student in our sample lived in a market in which television broadcasts were available.

Using an aggregate proxy for television ownership in place of a direct measure of each student's true childhood exposure will introduce some measurement error into our key independent variable. However, for well-known reasons, instrumental variables estimates will still be consistent, provided the measurement error is classical. Additionally, since our instruments are market-level rather than individual-level, there should be relatively little loss of power from estimating a first-stage model using aggregate dependent measures.

\subsection{First-stage and Reduced-form Estimates}

Before estimating model (1) using two-stage least squares, it will be helpful to examine the first stage of the model, as well as the reduced-form second stage of the model. Column (1) of table 4 presents estimates of the effect of the timing of television introduction on the number of preschool years of television exposure, which will serve as the first-stage model (2). We have divided cities into three categories: those in which television was introduced in 1948 or earlier, those in which it was introduced from 1949 to 1951, and those that began receiving television broadcasts in 1952 or later.

Observe first that, for a given grade, television exposure was lower the later television was introduced to the student's city. So, for example, students in grade 9 whose DMAs began receiving a television signal in 1952 or later were exposed to television for about .8 years less than ninthgraders whose DMAs received television in 1948 or earlier, and about .5 years less than those whose 
DMAs got sometime between 1949 and 1951. A similar pattern is present for students in grade 12.

Next, note that, holding constant the timing of television's introduction to a market, twelfthgraders on average had less preschool television exposure (between the ages of 2 and 6) than ninth graders, and much less than sixth graders (the omitted category). For example, twelfth-graders in cities that began receiving a television signal in 1952 or later had television in their homes for about 1.1 years less than sixth-graders in these same DMAs, and about .3 years less than ninth-graders. This is what we would expect, since twelfth-graders were born in 1948, ninth-graders were born in 1951, and sixth-graders were born in 1954. So in cities receiving television after 1948, ninth-graders were more likely than twelfth-graders to spend their preschool years in a city in which a television signal was available, and sixth-graders were almost certain to have grown up with a television in the household.

These findings complement the evidence in figure 4 in showing that the timing of broadcast availability had a substantial impact on television penetration and hence on students' exposure to television as young children. The F-test presented in table 4 definitively rejects the null hypothesis that the grade-timing introductions had no impact on exposure, and each of these interaction terms is strongly individually significant. ${ }^{13}$

The regression in column (1) of the table also serves to illustrate our identification strategy. The regression includes fixed effects for school and grade, and therefore identifies the effect of television's introduction by comparing the relative grade differentials across markets with different years of introduction. In this way, we can identify models purged of any level differences across grades or markets that might impact the outcomes of interest.

In column (2), we present a reduced-form second-stage estimate of the effect of our instruments on test scores. We use as our dependent variable the average of the student's (standardized) scores on the math, reading, verbal, and spatial reasoning tests. If television exposure exerted a negative long-term effect on cognitive skills, we would expect the coefficients on the grade-timing interactions in column (2) to move inversely with the coefficients in column (1). In other words, we would expect the students who had relatively less childhood television exposure to perform better on standardized tests. As the column shows, however, we do not see such a pattern. Although students whose areas

\footnotetext{
${ }^{13}$ The F-statistic in this first-stage model is sufficient to rule out any sizable weak instruments bias (Stock and Yogo, 2002).
} 
received television in 1949-1951 perform slightly better than those who received it in 1952 or later, these students perform worse than those whose areas received television in 1948 or sooner. Additionally, among students whose areas received television in 1949-1951, twelfth graders perform worse than ninth graders and sixth graders, despite having spent more time without television in their households.

An F-test of the null hypothesis that the grade-timing interactions had no effect on test scores fails to reject at conventional significance levels. Adding demographic controls in columns (3) and (4) improves the precision of our estimates by explaining a larger share of the variation in test scores. These more precise estimates show even less evidence of a negative effect of television. In column (4), where our standard errors are lowest, we find small point estimates on nearly all interaction terms, and the differences between these coefficients do not support the hypothesis of a negative effect of television on test scores.

\subsection{Two-stage Least Squares (2SLS) Estimates}

The estimates presented above allow us to test for an effect of television without placing any formal structure on how the introduction of television is related to television ownership. While such a test is a useful first step in evaluating the effects of the introduction of television, this lack of structure reduces statistical power, and makes it difficult to interpret the magnitude of the estimates. In this section, we present estimates of model (1) computed using two-stage least squares. Coefficients in these models will have a natural interpretation as the causal effect of a year of preschool television exposure on test scores.

Table 5 presents our 2SLS estimates. We present results for the average test score as well as for each individual component score. For each test, we present baseline estimates, estimates with demographic controls, and estimates with household demographics interacted with a student's grade. Adding controls should improve the precision of our estimates by leaving a smaller share of the overall variation in test scores unexplained.

The first column shows our estimates of the effect of an additional year of television exposure on the student's average test score, expressed in units of standard deviations (by grade). In general, we find small, statistically insignificant, and positive estimates. That is, if anything, our point estimates 
suggest that childhood television exposure improves a student's test scores. Adding controls tends to increase the point estimates and, consistent with expectations, decrease the standard errors of these estimates. In the final specification with demographic controls interacted with grade dummies, we are able to reject negative effects of television larger than about 0.034 of a standard deviation per year of exposure.

In the next column we report the estimated effect of television on mathematics performance. The point estimates are in general negative and statistically insignificant, and are slightly less precisely estimated than the estimates in the first column. Again, however, we find no evidence of a negative effect of television viewing. Turning to spatial reasoning, we find extremely small point estimates that range from slightly negative to slightly positive depending on the set of controls used. With our largest set of controls, we find a positive effect of about 0.003 standard deviations, but our confidence interval begins at -0.07 .

Although there is little reason to expect television to improve mathematical skill, it would not be surprising to learn that it has some benefits in verbal performance. For example, Rice (1983) argues that the presentation of verbal information on television is especially conducive to learning by young children. Rice and Woodsmall (1988) present laboratory evidence that children aged three and five can learn unfamiliar words from watching television. Our estimates provide some evidence for this view. Our point estimates on verbal and reading scores are always positive, with the effect on reading scores reaching nearly 0.06 standard deviations in the final specification. Indeed, this estimate is marginally statistically significant $(p=0.069)$. This in turn means that we can rule out even very small negative effects - our confidence interval in this specification excludes a negative effect on reading scores of about 0.004 standard deviations.

Television also exposes young children to a large number of facts, some of which might be retained into adolescence. Our estimates using students' general knowledge scores as a dependent variable support this possibility. We typically find nontrivial positive point estimates of about 0.07 standard deviations per year of television exposure. Although students in the sixth grade were not administered a general knowledge test, estimates from the contrast of ninth- and twelfth-graders are precise enough to rule out even very small negative effects on this outcome. ${ }^{14}$

\footnotetext{
${ }^{14}$ The fact that television exposure improves factual knowledge may also partly explain its effect on reading scores, since some evidence indicates that background knowledge can improve reading comprehension (Langer, 1984), at
} 
As an important caveat, we note that the effects we estimate are necessarily "local" to the students whose exposure to television was affected by the introduction of television (Angrist, 2004). A student whose household would never own a television regardless of whether broadcasts were available in the area will not be affected by variation in the timing of television signal introduction, even if the true effect of television exposure on the student is large. So, for example, students from richer households are likely to have more weight in our two-stage least squares estimates because these households tended to adopt television more rapidly. In section 4, we provide evidence on the heterogeneity in treatment effects in the student population and discuss how this heterogeneity is related to television viewership rates. ${ }^{15}$

\subsection{Specification Checks}

Are the instruments correlated with student characteristics?

The models presented above are valid under the assumption that our instruments $Z_{g c}$-interactions between the timing of television introduction and cohort - are orthogonal to the error term $\varepsilon_{i}$. Of course, it is by definition impossible to test this assumption. Some relevant information, however, can be obtained by asking whether television exposure is correlated with observable demographic characteristics $X_{i}$. Although the absence of such a correlation is not proof of the identifying assumption, it does provide some confidence that unobserved heterogeneity is unlikely to bias our estimates of the $\psi$ parameter.

To conduct a test of the orthogonality of our instruments to student demographics, we use the first-stage model (2) to create a predicted number of years of television exposure for each student. By regressing this predicted value on a set of demographic characteristics, we can test whether the variation in television exposure that is due to the timing of television introduction is correlated with observable student characteristics that might be expected to affect test scores. Because this predicted exposure measure varies only at the DMA-grade level, we conduct this test on "collapsed" data, where the demographics are measured as averages for each DMA-grade observation.

least if it is consistent with the information in the test passage (Alvermann, Smith, and Readence, 1985).

${ }^{15}$ We also present evidence in section 5 that television does not directly affect high-school completion rates. This makes it unlikely that selection into our 12th-grade sample is directly affected by exposure to television. Of course the sample of students who continue as far as 12 th grade is not random, and our estimates will necessarily be "local" to this subset of the population. 
The results of this test are presented in appendix table 1. None of the demographics has a statistically significant correlation with predicted television exposure. Additionally, an F-test of the joint hypothesis that none of the demographic characteristics is correlated with years of television exposure fails to reject at any conventional level $(p=0.371)$. Thus we find no evidence of a correlation between length of childhood television exposure and observable characteristics. ${ }^{16}$ This is true despite the fact that, as the appendix table also shows, these demographic characteristics are in most cases strong predictors of test scores. ${ }^{17}$

Are the instruments correlated with teacher characteristics?

It is possible that local trends in student characteristics are unrelated to the timing of television introduction but that changes in school resources and teacher quality are correlated with television entry. This could bias our findings if school resources affect test scores in ways not captured by student demographic characteristics. To address this issue we have tested whether differences in teacher characteristics across grades are correlated with the year of introduction of television, controlling for DMA characteristics as in our main specifications. To do this, we take advantage of the fact that the Coleman study collected a set of teacher surveys in addition to student surveys and test scores. While differences between teachers of different grades in 1965 may not perfectly capture time trends occurring simultaneously with the introduction of television in the 1950s, these tests can give us a partial look at whether heterogeneity in school resources is likely to be a source of bias in our estimates.

Appendix table 2 presents results of regressions of predicted television exposure by DMA-grade on the average characteristics of teachers who taught in that grade in 1965. Only one of the teacher characteristics (number of subjects taught) is statistically significantly related to predicted television exposure in that grade $(p=0.040)$. An F-test of the joint significance of the 12 teacher

\footnotetext{
${ }^{16}$ This approach allows us to test for a correlation between television introduction and trends across birth cohorts in household characteristics. Another source of concern might be changes over time in income or other local area characteristics, that might have affected different cohorts differently. To test for such a bias, we have estimated the relationship between the timing of the introduction of television and changes in income, population density, and adult schooling levels by DMA in the 1950s. We find no statistically significant relationship and no consistent direction of correlation. These findings further support the view that, conditional on our controls, there are no important time or cohort trends that are correlated with the timing of the introduction of television.

${ }^{17}$ Results are quite similar when we conduct the test on the individual-level data: we find no evidence of a correlation between predicted exposure and household characteristics. We have also conducted a parallel exercise in which we predict each student's average test score using her demographics, and then use this predicted measure as the dependent variable in $2 \mathrm{SLS}$ analysis paralleling table 5 . In this case, we again find no evidence of any correlation between our instruments and the demographic predictors of test scores.
} 
characteristics fails to reject at conventional significance levels $(p=0.111)$. Additionally, the signs of the coefficients suggest no clear pattern of more resources being associated with greater or lesser television exposure, again supporting the view that there were no systematic cross-grade trends in teacher quality that were correlated with the timing of the introduction of television.

As further evidence that television introduction was not correlated with trends in school quality, appendix table 3 shows regressions of the year of television introduction by U.S. state on cohort changes in schooling investments, as measured by Card and Krueger (1992). Given Card and Krueger's evidence that these measures are correlated with estimated returns to schooling, it is comforting that we find no evidence of a statistically significant (or even consistently signed) relationship between television introduction and this vector of school quality changes. ${ }^{18}$ Sample splits by place of residence in childhood.

In our calculations thus far we have implicitly assumed that the students in our sample grew up in the county - or at least the DMA — where they currently reside. Roughly 72 percent of students report having spent most of their lives in their current locality, with another 13 percent reporting having spent most of their lives in the same state but in a different city or town. ${ }^{19}$ Given the breadth of most DMAs, these figures suggest that our assignment of years of television introduction to sample students will be fairly accurate. However, it is possible to check more directly that our results are robust to excluding students who report living in a different state or country for most of their lives.

To do so, we separate students into two categories: those who grew up in their current locality of residence, or at least in the same state, and those who grew up in another state or country. If the positive estimates for reading and general knowledge reported in section 3.5 are robust, we would expect these effects to be stronger for the first group of students. The results, which we present in appendix table 4, do indeed show more positive effects of television for students who report growing up in their current state of residence. In almost all cases, we find higher (more positive) point estimates in the sample of students who grew up in the area than in the sample of students

\footnotetext{
${ }^{18}$ The expansion of kindergartens, another important trend in schooling investment, occurred after the television introduction period we study and is therefore not likely to be a confound in our analysis (Cascio, 2004).

${ }^{19}$ Follow-up data collected for a limited subsample suggests that students' responses to the survey question about where they spent the majority of their lives was accurate in 88 to 98 percent of cases. See appendix section 9.7 of Coleman (1966).
} 
who didn't. These findings lend support to the identifying assumptions in the model, and suggest that the slightly positive effects of television we estimate are not driven by unobserved area-level characteristics that are correlated with differences across grades in school achievement. ${ }^{20}$

Formal specification test.

Because we have multiple instruments, we can perform a test of overidentifying restrictions as an additional check on the validity of the instruments. A test using Hansen's J-statistic (Hansen, 1982; Hoxby and Paserman, 1998; Baum, Schaffer, and Stillman, 2002) cannot reject the null hypothesis that the instruments are uncorrelated with the error term $(J=3.119, p=0.3736)$.

\section{Heterogeneity in the Effects of Television}

Our results thus far focus on the effect of preschool television exposure on the test scores of the average student in our dataset. For many purposes, however, it will be important to know how the effects of television are distributed in the population, especially with respect to the socioeconomic status of the student's household. Theoretically, the direction of the relationship between parental human capital and the effect of television viewing on a child's cognitive development is ambiguous. On the one hand, it might be that richer or more educated parents are better able to select educational programming for their children to watch, thus making the effects of television more positive in households with greater parental resources. On the other hand, if television's effects come mostly through displacing other activities, a simple model of time allocation in the spirit of Becker (1965) would predict that children with more educated parents will gain less from television viewing, because for such children television is likely to displace human-capital-building activities. ${ }^{21}$

In this section, we offer evidence on the question of which children benefit the most (or are harmed the least) from television exposure. On the whole, our findings support the hypothesis that television is most beneficial in households with the least parental human capital. We find that the positive effects of television on test scores tend to be greatest for students whose parents do

\footnotetext{
${ }^{20}$ As an additional robustness check, we follow Gentzkow (2006) and re-estimate our models using rural counties only (results not shown). The point estimates from these models suggest similar conclusions to our estimates from the full sample, but the sample is about one-third the size, so the standard errors are substantially larger.

${ }^{21}$ The distinction between the direct effect of television content on the viewer and the indirect effect working through displacement of other activities is discussed by Gaddy (1986) and Beentjes and Van der Voort (1988) among others.
} 
not have a high-school degree, and for students in households where English is not the primary language. These findings seem most consistent with a model in which the effect of television viewing depends on the cognitive effects of the other activities that it displaces. We also discuss evidence supporting the rational-choice prediction that television viewing is greatest in households where its effects are most positive, which suggests that parental decisions about television viewing may vary in response to differences in television's effect on test scores.

Table 6 presents estimates of the effect of television exposure for students whose mothers do and do not have a high school education. ${ }^{22}$ In the first portion of the table, we repeat our basic 2SLS specification for these two subsamples. The estimated effect of a year of television exposure on the average test score is 0.04 for students whose mothers have less than a high-school education, and 0.01 for students whose mothers have a high-school degree. These estimates are not sufficiently precise to allow us to distinguish these two coefficients statistically, but the point estimates seem most consistent with the presence of superior substitutes for television in households with highly educated parents. The results for individual test scores nearly all support this hypothesis, and the effect of television on reading scores for students with non-high-school-educated mothers is positive and statistically significant.

One difficulty with interpreting these estimates is that, as figure 3 suggests, the diffusion of television was somewhat faster among the high-school-educated. Because our measures of television penetration are at the county level, they necessarily ignore within-county variation in the rate of diffusion. To adjust our estimates for a possible bias, we compute average television penetration from 1949-1955 for both high-school-educated and non-high-school-educated Gallup poll respondents (Roper Center for Public Opinion Research, 1949-1955). ${ }^{23}$ Using these averages, we then compute the ratio of each group's penetration to overall television penetration during this period, and scale each coefficient accordingly. Since high-school-educated respondents to the Gallup poll tended to be about 15 percent more likely to own televisions than the average respondent during

\footnotetext{
${ }^{22}$ We obtain similar results using father's education to split the sample rather than mother's education.

${ }^{23}$ Another way to avoid bias from different penetration rates would be to ask whether television's effect differs in counties with either high or low average education levels. The fact that lower education counties might also have less penetration is already corrected for in the estimates because our exposure measure is built from county-level penetration data. We do not report these results here, but they show a similar pattern: in counties with lower-thanmedian rates of high-school completion, we estimate larger positive television effects on reading, verbal and general knowledge scores than in counties with above-median education. The effect on reading scores in low-education counties is statistically significant at the 5 percent level.
} 
this period, we divide the coefficient (and standard error) on television exposure by 1.15 for students whose mothers have high-school degrees. Similarly, since Gallup respondents who did not complete high school were about 10 percent less likely to own a television than the average respondent, we divide the figures for students whose mothers did not complete high school by .9. As the second portion of the table shows, taking these adjustments into account makes little difference and leaves our qualitative conclusions unchanged. We still find that students with less educated fathers tend to benefit more from television exposure, and the coefficients are quite similar to those in the first portion of the table.

The fact that students in different households are likely to have watched different amounts of television as preschoolers could also lead to mechanical differences in the estimated treatment effect of television penetration. To correct for this, in the third portion of the table we further adjust our estimates to allow for differences in viewing intensity by parental education. We estimate preschool viewing hours for each respondent in the Coleman sample by scaling reported hours of current (1965) daily viewership to reflect the difference in viewing intensity between preschoolers and adolescents. ${ }^{24}$ We then rescale the coefficients in table 6 for the high and low-education groups by the ratio of the group's average daily preschool viewing hours to the overall average. Again, this adjustment does not make a substantial difference: the evidence still seems most consistent with the view that television is more beneficial for students whose parents are less educated.

The differences in viewing intensity between these two groups also suggest another important pattern in the data: the groups that we estimate to benefit most from television are also those where television watching is most intensive. Estimated average daily preschool viewing for children with high-school educated mothers is 8 percent lower than for children with mothers who do not have a high-school diploma. Although not conclusive, this pattern seems consistent with the rationalchoice hypothesis that parental choices respond to the incentives generated by cross-household differences in the cognitive effects of television.

In table 7 , we present several additional pieces of evidence on the heterogeneity in treatment effects across households. Because we find in table 6 that adjustments for differences in penetration

\footnotetext{
${ }^{24}$ We scale each student's reported hours of television viewing proportionally so that the average predicted preschool viewing in each grade is equal to Schramm, Lyle, and Parker's (1961) estimates of preschool viewing intensity in the 1950s.
} 
and viewing intensity do not substantially alter our conclusions, we focus here on unadjusted estimates. Given that our point estimates in section 3.5 suggest that the greatest gains from television accrued in verbal, reading, and general knowledge scores, we turn first to the question of whether these effects are larger in households where English language exposure was low. The results in the first two columns support this hypothesis. The estimated effects of television on verbal, reading, and general knowledge scores for students in non-English-speaking households are positive and nontrivial in magnitude, and the effect on reading scores is statistically significant $(p=0.044)$. For the sample of students whose family members primarily speak English, the point estimates are still positive, but are much smaller. The point estimates for math and spatial reasoning also suggest more positive effects for students in non-English-speaking households.

In the second two columns, we present results for white and non-white students. We find that non-white students benefit considerably more from television exposure than do white students. The point estimate of the effect on average test scores is more than 0.05 for non-white students, as compared to less than 0.01 for white students. For non-white students, the effect of television on verbal scores is positive and statistically significant, and the effects on reading and general knowledge scores are positive and marginally statistically significant. By contrast, we find statistically significant evidence that white students' general knowledge test scores are decreased by television exposure.

To combine the information from these various subsample comparisons, we take advantage of a question in the Coleman study that asks students how often they were read to at home prior to starting school. If the effects of television come mostly through displacement of other activities, we would expect television viewing to be most harmful to students in households where preschool reading by parents was common. To test this hypothesis, we interact our index of preschool reading frequency with television penetration. Formally, let $r_{i}$ be an index of preschool reading, where a value of 0 indicates that the student's parents never read to her prior to school and a value of 1 indicates that the student was regularly read to at home. We will estimate a model of the form

$$
y_{i}=\psi_{0}\left(\text { years }_{i}\right)+\psi_{1}\left(\text { years }_{i} \times r_{i}\right)+X_{i} \beta+\delta_{g}+W_{c} \gamma_{g}+\mu_{s}+\varepsilon_{i}
$$


As before, we will instrument for the expected number of years of preschool television ownership years $_{i}$ with our measures of the timing of television introduction. Because the preschool reading index $r_{i}$ may itself be endogenous to the introduction of television, and because it is likely to be measured with error, ${ }^{25}$ we will instrument for this measure with our vector of demographics $X_{i}{ }^{26}$

Table 8 presents our estimates of this interaction model. The first column shows results for average test scores. For students who were not read to as preschoolers, an additional year of television is estimated to raise average test scores by about 0.09 standard deviations. This coefficient is marginally statistically significant $(p=0.058)$. Moving to the top of the preschool reading distribution lowers this coefficient by a statistically significant 0.11 standard deviations, implying that students who were read to regularly would have experienced a small and statistically insignificant decline in average test scores as a result of an additional year of television exposure.

Looking across the columns of table 8, we see that similar patterns arise for the component test scores. In all cases television is estimated to have a positive effect on students whose parents did not read to them, and in most cases this positive effect is economically nontrivial and statistically significant at the 10 percent level. Also, the interaction between childhood reading and television exposure is consistently negative and nontrivial in size, and is often statistically significant, implying in most cases that the effect of television on students who were read to regularly is small and negative.

These findings provide further support for the hypothesis that children whose home environments were more conducive to learning were more negatively impacted by television. ${ }^{27}$ Moreover, although we do not have sufficient data to reliably adjust these interactions for differences in

\footnotetext{
${ }^{25}$ Response agreement between children and their parents on the question of preschool reading ranged from $60-80$ percent, depending on the student's grade (Coleman, 1966).

${ }^{26}$ More precisely, we will instrument for the vector $\left(\right.$ year $s_{i}$, year $s_{i} \times r_{i}$ ) with a vector of our television introduction instruments $Z_{g c}$ and the full set of instruments interacted with the full set of demographic characteristics $X_{i}$.

${ }^{27}$ To check the reasonableness of these estimates, we have estimated models that separate the effects of television at different ages. In particular, we have constructed, using county penetration data, a measure of each student's expected number of years of television exposure during ages 0 through 3 , and a separate measure for ages 4 through 6. Since the evidence we discuss in section 2 above indicates that the older group watched more television than the younger group during the 1950s, we would expect the effect of television ownership during ages 4 through 6 to be at least as large as that for age 0 through 3 . We find that this is indeed the case for the subsample with below-average predicted preschool reading. For this group, for whom our estimates suggest mostly positive effects of television on test scores, we generally find stronger positive effects for exposure at older ages (4 to 6) than for exposure at younger ages (0 to 3). Among students with above-average predicted preschool reading, our overall estimates suggest small negative or small positive effects of television, with absolute values of the effects generally larger for exposure at older ages.
} 
preschool viewing hours and television penetration, the results in table 6 suggest that accounting for such differences would not meaningfully alter these conclusions.

\section{Television and Non-cognitive Outcomes}

Thus far we have argued that television has no discernible negative effect on children's cognitive development, and even seems to have positive effects for some groups. But it may be that many of television's most important effects are on non-cognitive traits, such as interpersonal skills, which may have an important impact on economic outcomes (see, e.g., Heckman and Rubinstein, 2001). In this section, we first use the Coleman study data to estimate the effect of television exposure on several social and behavioral outcomes, and find little evidence of negative effects. We then use Census data to test for an effect of television on labor market outcomes. Although tests with Census data are less precise than those using Coleman study data, we again find no evidence of an effect of television on human capital. These findings suggest that our conclusions about the cognitive effects of television may generalize to non-cognitive effects, including those relevant to labor market performance.

\subsection{Evidence from the Coleman Study}

Table 9 reports 2SLS estimates of the effect of television exposure on various attitudinal and behavioral outcomes, using data from the Coleman study. These effects are mostly small, negative, and statistically insignificant. The main exception is a marginally statistically significant negative effect on the number of books a student reads during the summer. We also find a statistically insignificant and small positive effect on the number of hours the student spends on homework each day.

Notably, we find no evidence that preschool television exposure leads to less participation in membership organizations, including sports teams and school clubs. This finding seems especially interesting in light of Putnam's (2000) hypothesis that television may have contributed to a decline in "social capital" during the post-World War II period. Although our measure of club membership is not available for 6th graders, our estimates nevertheless do not support Putnam's hypothesis. Of course, these estimates refer only to the long-term impact of preschool exposure on social partici- 
pation, and therefore cannot speak directly to whether television had important contemporaneous effects on adult social capital.

\subsection{Evidence from the U.S. Census}

Our labor market data come from the Integrated Public Use Microdata Series (Ruggles et al, 2004). We extracted information on schooling attainment for individuals ages 25 and up born in 1948, 1951, and 1954 from the 1970, 1980, 1990, and 2000 1\% samples of the Census. We excluded individuals still attending school or in group housing.

Although the Census identifies sample individuals' metropolitan area of residence, it does not identify the metropolitan area in which an individual was born or raised. The Census does, however, classify individuals by state of birth. Since we are interested in the effects of childhood television exposure, we will use state of birth to figure out the year of television introduction relevant to a given sample individual. Although this measure is coarser than metropolitan area, the mobility of the U.S. population means that an adult's metropolitan area of residence is only a weak proxy for her metropolitan area of birth.

For each state, we compute the year in which the first county in the state received television. Then we follow our procedures from the previous section and calculate for each individual the expected number of years from ages 2-6 in which he or she lived in a state where television was available. Although the coarseness of our geographic identifiers makes this a somewhat noisier proxy than would be ideal, first stage models show a strong and statistically significant relationship between the timing of the introduction of television and expected television exposure.

Table 10 presents the results of two-stage least squares models of schooling completion and labor market earnings as a function of expected years of television exposure. We treat years of television exposure as endogenous, and use as instruments the interactions between our three categories of television introduction years with dummies for birth cohort. In parallel with our study of test scores, all specifications include fixed effects for birth cohort, Census year, and state of birth, as well as interactions between cohort dummies and $\log ($ state income) and $\log$ (state population). Standard errors are adjusted for clustering on state of birth.

Column (1) presents our estimates of the effect of television exposure on the probability of 
high school completion. We focus on the 1948, 1951, and 1954 birth cohorts, since this most closely resembles the sample we studied in the previous section. We find a small and statistically insignificant negative effect: an additional year of television exposure causes a decrease of just over one thousandth in the probability of completing high school. This suggests that our earlier estimates are not likely to be subject to composition bias due to childhood television exposure affecting dropout rates.

In column (2) we turn to effects on labor market earnings. We again find a statistically insignificant negative effect, implying that an additional year of television exposure decreases annual

earnings by about 4 percent. The confidence interval allows us to reject negative effects larger than about 11 percent. Although this estimate is not very precise, there is nothing in these estimates to suggest significant human capital effects of childhood television exposure.

One potential concern with this estimate is that television exposure may affect the selection of individuals into the labor market, which could introduce a bias in these estimates. In column (3) we therefore restrict attention to prime-age white males, whose rates of labor market participation are high enough to make severe composition bias unlikely. Our estimates in this case continue to show no evidence of negative effects of television.

Finally, unlike in our analysis of the Coleman study, in our analysis of Census data we are not restricted to using the 1948, 1951, and 1954 birth cohorts. In particular, with Census data we can study the effects of television exposure on cohorts born from 1930 to 1941, who began receiving television primarily between the ages of 7 to 18. Estimating our model for this cohort therefore allows us to take a first look at the question of whether the effects of television differ by age of exposure. As column (4) shows, we continue to find no evidence of a negative effect of television, even for those who first began receiving broadcasts at ages 7 to 18 .

\section{Conclusions}

In this paper we show that the introduction of television in the 1940s and 1950s had, if anything, positive effects on the achievement of students exposed to television as preschoolers. Our estimates therefore cast significant doubt on the hypothesis that television was responsible for the post- 
World War II declines in cognitive skills (Winn, 2002; Glenn, 1994) that Bishop (1989) links to the productivity growth slowdown of the 1980s. Our findings also suggest that much of the recent correlational evidence attributing negative developmental effects to childhood television viewing may require reevaluation.

Of course, it is possible that the type and variety of television content has changed over time in such a way as to alter its effects on cognitive development. We note, however, that congressional hearings on violence in television began as early as 1952 (Hoerrner, 1999), and that the popular children's shows of 2003 do not seem obviously less cognitively demanding than those of 1953 (see appendix table 5). Finally, as a first step toward understanding the effects of programming variety on cognitive development, we have re-estimated our models using variation in the number of television stations broadcasting as an independent variable, and find no evidence of negative effects of greater broadcast variety on cognitive development. 


\section{References}

[1] Donna E. Alvermann, Lynn C. Smith, and John E. Readence. Prior knowledge activation and the comprehension of compatible and incompatible text. Reading Research Quarterly, 20(4):420-436, Summer 1985.

[2] Joshua D. Angrist. Treatment effect heterogeneity in theory and practice. Economic Journal, 114(494):83, 2004.

[3] Erik Barnouw. Tube of Plenty: The Evolution of American Television. Oxford University Press, New York, 2nd rev. edition, 1990.

[4] Christopher F. Baum, Mark E. Schaffer, and Steven Stillman. Instrumental variables and GMM: Estimation and testing. Boston College Economics Working Paper, 545, November 2002 .

[5] Gary S. Becker. A theory of the allocation of time. Economic Journal, 75(299):493-517, 1965.

[6] Johannes W. J. Beentjes and Tom H. A. Van der Voort. Television's impact on children's reading skills: A review of research. Reading Research Quarterly, 23(4):389-413, 1988.

[7] Christopher Berry. School inflation. Education Next, pages 56-63, Fall 2004.

[8] Marianne Bertrand, Esther Duflo, and Sendhil Mullainathan. How much should we trust differences-in-differences estimates? Quarterly Journal of Economics, 119(1):249, 2004.

[9] John H. Bishop. Is the test score decline responsible for the productivity growth decline? American Economic Review, 79(1):178-197, March 1989.

[10] Dina L. G. Borzekowski and Thomas N. Robinson. The remote, the mouse, and the no. 2 pencil: The household media environment and academic achievement among third grade students. Arch Pediatr Adolesc Med, 159(7):607-613, 2005.

[11] David Card and Alan B. Krueger. Does school quality matter? Returns to education and the characteristics of public schools in the united states. Journal of Political Economy, 100(1):1-40, February 1992.

[12] Elizabeth U. Cascio. Schooling attainment and the introduction of kindergartens into public schools. University of California, Davis mimeograph, April 2004.

[13] Dimitri A. Christakis, Frederick J. Zimmerman, David L. DiGiuseppe, and Carolyn A. McCarty. Early television exposure and subsequent attentional problems in children. Pediatrics, 113(4):708-713, 2004.

[14] James Samuel Coleman, United States Office of Education, and National Center for Educational Statistics. Equality of educational opportunity. U.S. Dept. of Health Education and Welfare Office of Education, Washington, 1966.

[15] Stefano DellaVigna and Ethan Kaplan. The Fox News effect: Media bias and voting. University of California, Berkeley Mimeograph, 2005.

[16] Simeon Djankov, Caralee McLiesh, Tatiana Nenova, and Andrei Shleifer. Who owns the media? Journal of Law and Economics, 46(2):341-81, 2003. 
[17] Ronald G. Ehrenberg and Dominic J. Brewer. Did teachers' verbal ability and race matter in the 1960s? Coleman revisited. Economics of Education Review, 14(1):1, 1995.

[18] Azriel Louis Eisenberg. Children and radio programs: a study of more than three thousand children in the New York metropolitan area. Columbia University Press, New York, 1936.

[19] Roper Center for Public Opinion Research. Gallup Polls, volume USAIPO19490441, USAIPO1950-0460, USAIPO1951-0470, USAIPO1953-0513, USAIPO19530514, USAIPO1953-0522, USAIPO1954-0529, USAIPO1954-0537, USAIPO1955-0546, USAIPO1955-0549. Gallup Organization, 1949-1955.

[20] Fox Meadow School PTA. Radio for children-parents listen in. Child Study Magazine, XI(7), 1933.

[21] Gary D. Gaddy. Television's impact on high school achievement. Public Opinion Quarterly, 50(3):340-359, 1986.

[22] D. A. Gentile, C. Oberg, N. E. Sherwood, M. Story, D. A. Walsh, and M. Hogan. Well-child visits in the video age: pediatricians and the American Academy of Pediatrics' guidelines for children's media use. Pediatrics, 114(5):1235-41, 2004.

[23] Matthew Gentzkow. Television and voter turnout. Quarterly Journal of Economics, 121(3), August 2006. Forthcoming.

[24] Matthew Gentzkow and Jesse M. Shapiro. Media bias and reputation. Journal of Political Economy, 114(2), April 2006. Forthcoming.

[25] Matthew A. Gentzkow and Jesse M. Shapiro. Media, education, and anti-Americanism in the Muslim world. Journal of Economic Perspectives, Summer 2004.

[26] Norval D. Glenn. Television watching, newspaper reading, and cohort differences in verbal ability. Sociology of Education, 67(3):216-230, July 1994.

[27] Zvi Griliches. Hybrid corn: An exploration in the economics of technological change. Econometrica, Journal of the Econometric Society, 25(4):501-522, 1957.

[28] Zvi Griliches and William M. Mason. Education, income, and ability. Journal of Political Economy, 80(3):S74-S103, May-June 1972.

[29] Robert J. Hancox, Barry J. Milne, and Richie Poulton. Association of television viewing during childhood with poor educational achievement. Arch Pediatr Adolesc Med, 159(7):614$618,2005$.

[30] Lars Peter Hansen. Large sample properties of generalized method of moments estimators. Econometrica, 50(4):1029-1054, July 1982.

[31] Eric A. Hanushek and John F. Kain. On the value of Equality of Educational Opportunity as a guide to public policy. In Frederick Mosteller and Daniel P. Moynihan, editors, On Equality of Educational Opportunity, pages 116-145. Random House, New York, 1972.

[32] James J. Heckman. Randomization as an instrumental variable. Review of Economics and Statistics, 78(2):336-341, May 1996. 
[33] James J. Heckman and Yona Rubinstein. The importance of noncognitive skills: Lessons from the GED testing program. American Economic Review, 91(2):145, 2001.

[34] James J. Heckman and Guilherme Sedlacek. Heterogeneity, aggregation, and market wage functions: An empirical model of self-selection into the labor market. Journal of Political Economy, 93(6):1077-1125, December 1985.

[35] Keisha L. Hoerrner. The forgotten battles: Congressional hearings on television violence in the 1950s. Manship School of Mass Communication Mimeograph, 1999.

[36] Caroline M. Hoxby and M. Daniele Paserman. Overidentification tests with grouped data. NBER Technical Working Paper, 223, February 1998.

[37] Judith A. Langer. Examining background knowledge and text comprehension. Reading Research Quarterly, 19(4):468-481, Summer 1984.

[38] Steven D. Levitt and Stephen J. Dubner. Freakonomics: a rogue economist explores the hidden side of everything. William Morrow, New York, 1st edition, 2005.

[39] Eleanor E. Maccoby. Television: Its impact on school children. Public Opinion Quarterly, 15(3):421-444, 1951.

[40] Brent R. Moulton. An illustration of a pitfall in estimating the effects of aggregate variables on micro unit. Review of Economics and Statistics, 72(2):334, 1990.

[41] American Academy of Pediatrics. American academy of pediatrics: Children, adolescents, and television. Pediatrics, 107(2):423-6, 2001.

[42] Robert D. Putnam. Bowling Alone. Simon and Schuster, New York, NY, 2000.

[43] Mabel L. Rice. The role of television in language acquisition. Developmental Review, 3:221-224, 1983.

[44] Mabel L. Rice and Linda Woodsmall. Lessons from television: Children's word learning when viewing. Child Development, 59(2):420-429, 1988.

[45] Sydney Roslow. Programming trends. Television, 9(4):22-23, 1952.

[46] A. D. Roy. Some thoughts on the distribution of earnings. Oxford Economic Papers, 3(2):135146, June 1951.

[47] Steven Ruggles, Matthew Sobek, Trent Alexander, Catherine A. Fitch, Ronald Goeken, Patricia Kelly Hall, Miriam King, and Chad Ronnander. Integrated Public Use Microdata Series: Version 3.0. www.ipums.org, 2004.

[48] Wilbur Schramm, Jack Lyle, and Edwin B. Parker. Television in the lives of our children. Stanford University Press, Stanford, CA, June 1961.

[49] Hugh Richard Slotten. Radio and Television Regulation: Broadcast Technology in the United States, 1920-1960. Johns Hopkins University Press, Baltimore, 2000.

[50] Christopher H. Sterling. Electronic Media: A Guide to Trends in Broadcasting and Newer Technologies, 1920-1983. Praeger, New York, N.Y., 1984. 
[51] Christopher H. Sterling and John M. Kittross. Stay Tuned: A History of American Broadcasting. LEA's communication series. Lawrence Erlbaum Associates, Mahwah, N.J., 3rd edition, 2001.

[52] James H. Stock and Motohiro Yogo. Testing for weak instruments in linear IV regression. NBER Technical Working Paper 284, 2002.

[53] V. C. Strasburger. Does television affect learning and school performance? Pediatrician, 13(2-3):141-7, 1986.

[54] David Stromberg. Radio's impact on public spending. Quarterly Journal of Economics, 119(1):189-221, 2004.

[55] Television Bureau of Advertising. TV basics 2003: A report on the growth and scope of television. http://www.tvb.org/rcentral/mediattrendstracks/tvbasics, October 192003.

[56] Television Digest. Television Factbook, volume 16. Television Factbook, inc., Washington DC, 1953.

[57] Television Magazine. Programming. Television, 5(1):41-43, 1948.

[58] Television Magazine. Four hundred thousand dollars a week for the children's market. Television, 8(8):21-22, 1951.

[59] Television Magazine. The child audience. Television, 12(4):83-84, 1955.

[60] Television Magazine. Market Book. Frederick Kugel Company, New York, various years.

[61] Judith Page Van Evra. Television and child development. Lawrence Erlbaum Associates, Mahwah, N.J., 1998.

[62] Elizabeth A. Vandewater, David S. Bickham, June H. Lee, Hope M. Cummings, Ellen A. Wartella, and Victoria J. Rideout. When the television is always on: Heavy television exposure and young children's development. American Behavioral Scientist, 48(5):562-577, 2005.

[63] Marie Winn. The plug-in drug: Television, computers, and family life. Penguin, New York, March 2002.

[64] Willard Wirtz et al. On Further Examination: Report of the Advisory Panel on the Scholastic Aptitude Test Score Decline. College Entrance Examination Board, New York, 1977.

[65] Madeline Zavodny. Does watching television rot your mind? Evidence of the effect on test scores. Economics of Education Review, 2006. Forthcoming.

[66] Frederick J. Zimmerman and Dimitri A. Christakis. Children's television viewing and cognitive outcomes: A longitudinal analysis of national data. Arch Pediatr Adolesc Med, 159(7):619-625, 2005 . 
Table 1 Variation in the timing of television introduction

Panel A: Before correcting for $\log ($ income) and $\log ($ population):

\begin{tabular}{ll}
\hline \hline First 10 DMAs to receive television & Last 10 DMAs to receive television \\
\hline Chicago (IL) & North Platte (NE) \\
Albany-Schenectady-Troy (NY) & Glendive (MT) \\
Los Angeles (CA) & Helena (MT) \\
New York (NY) & Presque Isle (ME) \\
Philadelphia (PA) & Casper-Riverton (WY) \\
Washington (DC) & Corpus Christi (TX) \\
St. Louis (MO) & Juneau (AK) \\
Detroit (MI) & Tallahassee-Thomasville (FL) \\
Toledo (OH) & Columbus-Tupelo-West Point (MS) \\
Baltimore (MD) & Laredo (TX) \\
Hartford-New Haven (CT) & Hattiesburg-Laurel (MS) \\
\hline \hline
\end{tabular}

Panel B: After correcting for $\log ($ income $)$ and $\log ($ population):

\begin{tabular}{ll}
\hline \hline First 10 DMAs to receive television & Last 10 DMAs to receive television \\
\hline Albany-Schenectady-Troy (NY) & Sacramento-Modesto (CA) \\
Erie (PA) & Portland (OR) \\
Richmond-Petersburg (VA) & Corpus Christi (TX) \\
Salt Lake City (UT) & Burlington-Plattsburgh (VT/NY) \\
Zanesville (OH) & Orlando-Daytona Beach (FL) \\
Toledo (OH) & Tampa-St. Petersburg (FL) \\
Memphis (TN) & Casper-Riverton (WY) \\
Binghamton (NY) & Wichita (KS) \\
Utica (NY) & Wilkes-Barre (PA) \\
Albuquerque-Santa Fe (NM) & Beaumont (TX) \\
Omaha (NE) & Denver (CO) \\
\hline \hline
\end{tabular}

Notes: Panel B shows top and bottom 10 DMAs sorted by residuals from an OLS regression of year of first television broadcast on $\log$ (DMA population) in 1960 and $\log$ (DMA income) in 1959. 
Table 2 The correlates of television viewing intensity

\begin{tabular}{|c|c|c|}
\hline & $\begin{array}{l}\text { Number of hours of } \\
\text { television viewing } \\
\text { (1) }\end{array}$ & $\begin{array}{c}\text { Standardized average } \\
\text { test score } \\
(2)\end{array}$ \\
\hline Male & $\begin{array}{c}0.0415 \\
(0.0080)\end{array}$ & $\begin{array}{l}-0.0524 \\
(0.0066)\end{array}$ \\
\hline $\begin{array}{l}\text { English not spoken } \\
\text { at home }\end{array}$ & $\begin{array}{c}0.0009 \\
(0.0104)\end{array}$ & $\begin{array}{l}-0.1798 \\
(0.0079)\end{array}$ \\
\hline $\begin{array}{l}\text { Father's education } \\
\text { (index) }\end{array}$ & $\begin{array}{l}-0.0509 \\
(0.0034)\end{array}$ & $\begin{array}{c}0.0544 \\
(0.0016)\end{array}$ \\
\hline $\begin{array}{l}\text { Mother's education } \\
\text { (index) }\end{array}$ & $\begin{array}{l}-0.0306 \\
(0.0043)\end{array}$ & $\begin{array}{c}0.0481 \\
(0.0015)\end{array}$ \\
\hline White & $\begin{array}{l}-0.1750 \\
(0.0242)\end{array}$ & $\begin{array}{c}0.3858 \\
(0.0294)\end{array}$ \\
\hline $\begin{array}{l}\text { Lives with } \\
\text { biological father }\end{array}$ & $\begin{array}{l}-0.0537 \\
(0.0071)\end{array}$ & $\begin{array}{c}0.0757 \\
(0.0057)\end{array}$ \\
\hline $\begin{array}{l}\text { Lives with } \\
\text { biological mother }\end{array}$ & $\begin{array}{c}0.1029 \\
(0.0107)\end{array}$ & $\begin{array}{c}0.1762 \\
(0.0059)\end{array}$ \\
\hline \multicolumn{3}{|l|}{ Family has } \\
\hline Telephone & $\begin{array}{c}0.1199 \\
(0.0147)\end{array}$ & $\begin{array}{c}0.1069 \\
(0.0079)\end{array}$ \\
\hline Record player & $\begin{array}{c}0.1716 \\
(0.0083)\end{array}$ & $\begin{array}{c}0.0226 \\
(0.0044)\end{array}$ \\
\hline Refrigerator & $\begin{array}{c}0.3482 \\
(0.0321)\end{array}$ & $\begin{array}{c}0.4070 \\
(0.0143)\end{array}$ \\
\hline Vacuum & $\begin{array}{l}-0.0085 \\
(0.0115)\end{array}$ & $\begin{array}{c}0.0610 \\
(0.0092)\end{array}$ \\
\hline Car & $\begin{array}{c}0.0446 \\
(0.0137)\end{array}$ & $\begin{array}{c}0.0607 \\
(0.0093)\end{array}$ \\
\hline $\begin{array}{l}F(12,135) \\
(p-\text { value })\end{array}$ & $\begin{array}{c}235.53 \\
(<0.0001)\end{array}$ & $\begin{array}{c}708.12 \\
(<0.0001)\end{array}$ \\
\hline $\begin{array}{l}\text { Number of observations } \\
\text { Number of schools } \\
\text { Number of DMAs }\end{array}$ & $\begin{array}{c}335981 \\
800 \\
136\end{array}$ & $\begin{array}{c}346562 \\
800 \\
136\end{array}$ \\
\hline
\end{tabular}

Notes: Standard errors in parentheses are adjusted for clustering on DMA. Average test score is standardized to have a mean of zero and a standard deviation of unity within each grade. All regressions include fixed effects for school and grade and interactions between grade and $\log$ (DMA population) in 1960 and $\log$ (DMA total income) in 1959. Dummies are included to indicate missing values for demographic controls. 
Table 3 Correlational estimates of the effect of television viewing on cognitive skills

\begin{tabular}{|c|c|c|c|c|c|c|}
\hline \multirow{2}{*}{\multicolumn{2}{|c|}{$\begin{array}{c}\text { Standardized } \\
\text { average } \\
\text { test score }\end{array}$}} & \multicolumn{5}{|c|}{ Standardized component: } \\
\hline & & Math & $\begin{array}{l}\text { Spatial } \\
\text { reasoning }\end{array}$ & Verbal & Reading & $\begin{array}{c}\text { General } \\
\text { knowledge }\end{array}$ \\
\hline \multicolumn{7}{|c|}{ Controls for family background: } \\
\hline $\begin{array}{l}\text { Daily hours of television } \\
\text { viewing (current) }\end{array}$ & $\begin{array}{c}0.0103 \\
(0.0010)\end{array}$ & $\begin{array}{l}-0.0117 \\
(0.0011)\end{array}$ & $\begin{array}{c}0.0357 \\
(0.0011)\end{array}$ & $\begin{array}{c}0.0067 \\
(0.0010)\end{array}$ & $\begin{array}{c}0.0089 \\
(0.0010)\end{array}$ & $\begin{array}{l}-0.0099 \\
(0.0013)\end{array}$ \\
\hline Number of observations & 335981 & 335981 & 335981 & 335981 & 335981 & 219815 \\
\hline \multicolumn{7}{|l|}{ Controls for family wealth: } \\
\hline $\begin{array}{l}\text { Daily hours of television } \\
\text { viewing (current) }\end{array}$ & $\begin{array}{l}-0.0280 \\
(0.0011)\end{array}$ & $\begin{array}{l}-0.0429 \\
(0.0011)\end{array}$ & $\begin{array}{c}0.0051 \\
(0.0011)\end{array}$ & $\begin{array}{l}-0.0326 \\
(0.0011)\end{array}$ & $\begin{array}{l}-0.0252 \\
(0.0011)\end{array}$ & $\begin{array}{l}-0.0501 \\
(0.0014)\end{array}$ \\
\hline Number of observations & 335981 & 335981 & 335981 & 335981 & 335981 & 219815 \\
\hline
\end{tabular}

Notes: All regressions include fixed effects for grade. All dependent measures are standardized to have a mean of zero and a standard deviation of unity within each grade. Family background includes controls for gender, English spoken at home, father's education, mother's education, race, lives with biological father, and lives with biological mother. Family wealth includes separate dummies for whether student's family has a telephone, a record player, a refrigerator, a vacuum cleaner, or a car. Dummies are included to indicate missing values for controls. General knowledge test scores are only available for students in grades 9 and 12 . 
Table 4 Reduced-form estimates of the effect of television exposure on cognitive skills

\begin{tabular}{|c|c|c|c|c|}
\hline & \multirow{2}{*}{$\begin{array}{l}\text { Number of years of } \\
\text { television exposure } \\
\text { (1) }\end{array}$} & \multicolumn{3}{|c|}{$\begin{array}{c}\text { Standardized average } \\
\text { test score }\end{array}$} \\
\hline & & $(2)$ & $(3)$ & $(4)$ \\
\hline \multicolumn{5}{|l|}{ TV introduced in 1949-1951 } \\
\hline$\times$ Grade 9 & $\begin{array}{l}-0.2624 \\
(0.0841)\end{array}$ & $\begin{array}{l}-0.0229 \\
(0.0440)\end{array}$ & $\begin{array}{l}-0.0002 \\
(0.0296)\end{array}$ & $\begin{array}{l}-0.0076 \\
(0.0291)\end{array}$ \\
\hline$\times$ Grade 12 & $\begin{array}{l}-0.7137 \\
(0.1628)\end{array}$ & $\begin{array}{l}-0.0480 \\
(0.0477)\end{array}$ & $\begin{array}{l}-0.0312 \\
(0.0343)\end{array}$ & $\begin{array}{l}-0.0347 \\
(0.0319)\end{array}$ \\
\hline \multicolumn{5}{|l|}{ TV introduced in 1952 or later } \\
\hline$\times$ Grade 9 & $\begin{array}{l}-0.7641 \\
(0.1070)\end{array}$ & $\begin{array}{l}-0.0066 \\
(0.0444)\end{array}$ & $\begin{array}{c}0.0033 \\
(0.0333)\end{array}$ & $\begin{array}{l}-0.0077 \\
(0.0338)\end{array}$ \\
\hline$\times$ Grade 12 & $\begin{array}{l}-1.0862 \\
(0.2834)\end{array}$ & $\begin{array}{c}0.0017 \\
(0.0493)\end{array}$ & $\begin{array}{c}0.0001 \\
(0.0393)\end{array}$ & $\begin{array}{l}-0.0140 \\
(0.0371)\end{array}$ \\
\hline School and grade fixed effects? & YES & YES & YES & YES \\
\hline DMA demographics $\times$ grade? & YES & YES & YES & YES \\
\hline Student demographics? & $\mathrm{NO}$ & $\mathrm{NO}$ & YES & YES \\
\hline Demographics $\times$ grade? & $\mathrm{NO}$ & $\mathrm{NO}$ & $\mathrm{NO}$ & YES \\
\hline$F(4,135)$ statistic & 16.54 & 0.90 & 0.79 & 0.61 \\
\hline (p-value) & $(<0.0001)$ & 0.4640 & 0.5345 & 0.6547 \\
\hline Number of observations & 346562 & 346562 & 346562 & 346562 \\
\hline Number of schools & 800 & 800 & 800 & 800 \\
\hline Number of DMAs & 136 & 136 & 136 & 136 \\
\hline
\end{tabular}

Notes: Standard errors in parentheses are adjusted for clustering on DMA. DMA demographics include $\log$ (DMA population) in 1960 and $\log$ (DMA total income) in 1959. Student demographics includes controls for gender, English spoken at home, father's education, mother's education, race, lives with biological father, lives with biological mother, and separate dummies for whether student's family has a telephone, a record player, a refrigerator, a vacuum cleaner, or a car. Dummies are included to indicate missing values for demographic controls. 
Table 5 Structural (2SLS) estimates of the effect of television exposure on cognitive skills

\begin{tabular}{|c|c|c|c|c|c|c|}
\hline \multirow{2}{*}{\multicolumn{2}{|c|}{$\begin{array}{c}\text { Standardized } \\
\text { average } \\
\text { test score } \\
\end{array}$}} & \multicolumn{5}{|c|}{ Standardized component: } \\
\hline & & Math & $\begin{array}{c}\text { Spatial } \\
\text { reasoning }\end{array}$ & Verbal & Reading & $\begin{array}{c}\text { General } \\
\text { knowledge }\end{array}$ \\
\hline \multicolumn{7}{|c|}{ Effect of number of years of preschool television exposure: } \\
\hline Baseline & $\begin{array}{c}0.0129 \\
(0.0385)\end{array}$ & $\begin{array}{l}-0.0192 \\
(0.0441)\end{array}$ & $\begin{array}{l}-0.0071 \\
(0.0482)\end{array}$ & $\begin{array}{c}0.0268 \\
(0.0405)\end{array}$ & $\begin{array}{c}0.0470 \\
(0.0348)\end{array}$ & $\begin{array}{c}0.0494 \\
(0.0493)\end{array}$ \\
\hline $\begin{array}{l}\text { Baseline }+ \\
\text { demographics }\end{array}$ & $\begin{array}{c}0.0140 \\
(0.0309)\end{array}$ & $\begin{array}{l}-0.0154 \\
(0.0377)\end{array}$ & $\begin{array}{l}-0.0046 \\
(0.0459)\end{array}$ & $\begin{array}{c}0.0254 \\
(0.0295)\end{array}$ & $\begin{array}{c}0.0461 \\
(0.0296)\end{array}$ & $\begin{array}{c}0.0696 \\
(0.0404)\end{array}$ \\
\hline $\begin{array}{l}\text { Baseline }+ \\
\text { demographics } \times \text { grade }\end{array}$ & $\begin{array}{c}0.0225 \\
(0.0280)\end{array}$ & $\begin{array}{l}-0.0179 \\
(0.0380)\end{array}$ & $\begin{array}{c}0.0028 \\
(0.0388)\end{array}$ & $\begin{array}{c}0.0294 \\
(0.0290)\end{array}$ & $\begin{array}{c}0.0557 \\
(0.0304)\end{array}$ & $\begin{array}{c}0.0688 \\
(0.0409)\end{array}$ \\
\hline Number of observations & 346562 & 346562 & 346562 & 346562 & 346562 & 226487 \\
\hline Number of schools & 800 & 800 & 800 & 800 & 800 & 705 \\
\hline Number of DMAs & 136 & 136 & 136 & 136 & 136 & 134 \\
\hline
\end{tabular}

Notes: Estimates are from two-stage least squares models with interactions between grade and category of television introduction year used as instruments for years of television exposure. Standard errors in parentheses are adjusted for clustering on DMA. All dependent measures are standardized to have a mean of zero and a standard deviation of unity within each grade. Baseline includes fixed effects for school and grade and interactions between grade and $\log$ (DMA population) in 1960 and $\log$ (DMA total income) in 1959. Demographics includes controls for gender, English spoken at home, father's education, mother's education, race, lives with biological father, lives with biological mother, and separate dummies for whether student's family has a telephone, a record player, a refrigerator, a vacuum cleaner, or a car. Dummies are included to indicate missing values for demographic controls. General knowledge test scores are only available for students in grades 9 and 12 . 
Table 6 Mother's education and the effects of television exposure

\begin{tabular}{|c|c|c|c|c|c|c|}
\hline \multirow{2}{*}{\multicolumn{2}{|c|}{$\begin{array}{c}\text { Standardized } \\
\text { average } \\
\text { test score }\end{array}$}} & \multicolumn{5}{|c|}{ Standardized component: } \\
\hline & & Math & $\begin{array}{c}\text { Spatial } \\
\text { reasoning }\end{array}$ & Verbal & Reading & $\begin{array}{c}\text { General } \\
\text { knowledge }\end{array}$ \\
\hline \multicolumn{7}{|c|}{$\begin{array}{l}\text { Unadjusted estimates } \\
\text { Does mother have high school degree? }\end{array}$} \\
\hline Yes & $\begin{array}{c}0.0135 \\
(0.0298)\end{array}$ & $\begin{array}{l}-0.0477 \\
(0.0423)\end{array}$ & $\begin{array}{c}0.0125 \\
(0.0396)\end{array}$ & $\begin{array}{c}0.0308 \\
(0.0295)\end{array}$ & $\begin{array}{c}0.0450 \\
(0.0317)\end{array}$ & $\begin{array}{c}0.0074 \\
(0.0531)\end{array}$ \\
\hline No & $\begin{array}{c}0.0418 \\
(0.0335)\end{array}$ & $\begin{array}{c}0.0289 \\
(0.0355)\end{array}$ & $\begin{array}{l}-0.0342 \\
(0.0448)\end{array}$ & $\begin{array}{c}0.0482 \\
(0.0400)\end{array}$ & $\begin{array}{c}0.0942 \\
(0.0455)\end{array}$ & $\begin{array}{c}0.0657 \\
(0.0488)\end{array}$ \\
\hline
\end{tabular}

Adjusted for differences in average television penetration, 1949-1955

Does mother have high school degree?

$\begin{array}{lcccccc}\text { Yes } & 0.0117 & -0.0414 & 0.0108 & 0.0267 & 0.0390 & 0.0064 \\ \text { (Share with TV }=0.43) & (0.0259) & (0.0367) & (0.0344) & (0.0256) & (0.0275) & (0.0461) \\ \text { No } & 0.0469 & 0.0324 & -0.0383 & 0.0540 & 0.1056 & 0.0737 \\ \text { (Share with TV }=0.34) & (0.0376) & (0.0398) & (0.0502) & (0.0449) & (0.0510) & (0.0547)\end{array}$

Adjusted for differences in average daily preschool viewing hours and television penetration Does mother have high school degree?

$\begin{array}{lcccccc}\text { Yes } & 0.0124 & -0.0439 & 0.0115 & 0.0283 & 0.0414 & 0.0068 \\ \text { (Average hours = 1.30) } & (0.0274) & (0.0389) & (0.0364) & (0.0271) & (0.0292) & (0.0489) \\ \text { No } & 0.0459 & 0.0318 & -0.0376 & 0.0530 & 0.1035 & 0.0722 \\ \text { (Average hours = 1.41) } & (0.0368) & (0.0390) & (0.0492) & (0.0440) & (0.0500) & (0.0536)\end{array}$

Notes: Estimates are from two-stage least squares models with samples split by mother's education. Standard errors in parentheses are adjusted for clustering on DMA. All dependent measures are standardized to have a mean of zero and a standard deviation of unity within each grade. All specifications include fixed effects for school and grade, interactions between grade and $\log$ (DMA population) in 1960 and $\log$ (DMA total income) in 1959, controls for gender, English spoken at home, father's education, race, lives with biological father, lives with biological mother, and separate dummies for whether student's family has a telephone, a record player, a refrigerator, a vacuum cleaner, or a car, and demographic controls interacted with grade dummies. Dummies are included to indicate missing values for demographic controls. General knowledge test scores are only available for students in grades 9 and 12 . 
Table 7 Heterogeneity in the effects of television exposure

\begin{tabular}{ccccc}
\hline \hline & \multicolumn{2}{c}{ English at home? } & \multicolumn{2}{c}{ White? } \\
& Yes & No & Yes & No \\
& $(1)$ & $(2)$ & $(3)$ & $(4)$ \\
\hline Effect of number of years of preschool television exposure: & \\
Average & 0.0157 & 0.0766 & 0.0026 & 0.0526 \\
& $(0.0278)$ & $(0.0481)$ & $(0.0263)$ & $(0.0491)$ \\
Math & -0.0283 & 0.0352 & -0.0293 & -0.0055 \\
& $(0.0391)$ & $(0.0478)$ & $(0.0407)$ & $(0.0447)$ \\
Spatial reasoning & -0.0050 & 0.0592 & 0.0225 & -0.0345 \\
& $(0.0363)$ & $(0.0610)$ & $(0.0279)$ & $(0.0579)$ \\
Verbal & 0.0252 & 0.0740 & -0.0191 & 0.1167 \\
& $(0.0286)$ & $(0.0531)$ & $(0.0189)$ & $(0.0473)$ \\
Reading & 0.0528 & 0.0927 & 0.0273 & 0.0922 \\
& $(0.0333)$ & $(0.0455)$ & $(0.0388)$ & $(0.0545)$ \\
General knowledge & 0.0260 & 0.2123 & -0.0945 & 0.1401 \\
& $(0.0379)$ & $(0.1558)$ & $(0.0425)$ & $(0.0790)$ \\
\hline Number of observations: & & & & \\
All grades & 280455 & 57537 & 211613 & 126912 \\
Grades 9-12 & 186126 & 36235 & 142379 & 79746 \\
\hline \hline
\end{tabular}

Notes: Estimates are from two-stage least squares models with interactions between grade and category of television introduction year used as instruments for years of television exposure. Standard errors in parentheses are adjusted for clustering on DMA. All dependent measures are standardized to have a mean of zero and a standard deviation of unity within each grade. All specifications include fixed effects for school and grade, interactions between grade and $\log$ (DMA population) in 1960 and $\log$ (DMA total income) in 1959, controls for gender, English spoken at home, father's education, mother's education, race, lives with biological father, lives with biological mother, and separate dummies for whether student's family has a telephone, a record player, a refrigerator, a vacuum cleaner, or a car, and demographic controls interacted with grade dummies. Controls for variable on which the sample is split are excluded. Dummies are included to indicate missing values for demographic controls. General knowledge test scores are only available for students in grades 9 and 12 . 
Table 8 Parental investments and the effects of television exposure

\begin{tabular}{|c|c|c|c|c|c|c|}
\hline & \multirow{2}{*}{$\begin{array}{c}\text { Standardized } \\
\text { average } \\
\text { test score }\end{array}$} & \multicolumn{5}{|c|}{ Standardized component: } \\
\hline & & Math & $\begin{array}{l}\text { Spatial } \\
\text { reasoning }\end{array}$ & Verbal & Reading & $\begin{array}{c}\text { General } \\
\text { knowledge }\end{array}$ \\
\hline $\begin{array}{l}\text { Years of preschool } \\
\text { television exposure }\end{array}$ & $\begin{array}{c}0.0879 \\
(0.0460)\end{array}$ & $\begin{array}{c}0.0474 \\
(0.0471)\end{array}$ & $\begin{array}{c}0.0786 \\
(0.0447)\end{array}$ & $\begin{array}{c}0.0791 \\
(0.0529)\end{array}$ & $\begin{array}{c}0.0932 \\
(0.0479)\end{array}$ & $\begin{array}{c}0.0907 \\
(0.0598)\end{array}$ \\
\hline $\begin{array}{l}\text { Years of exposure } \\
\times \text { Preschool reading index }\end{array}$ & $\begin{array}{l}-0.1126 \\
(0.0483)\end{array}$ & $\begin{array}{l}-0.0952 \\
(0.0481)\end{array}$ & $\begin{array}{l}-0.1110 \\
(0.0353)\end{array}$ & $\begin{array}{l}-0.0943 \\
(0.0534)\end{array}$ & $\begin{array}{l}-0.0912 \\
(0.0461)\end{array}$ & $\begin{array}{l}-0.0824 \\
(0.0549)\end{array}$ \\
\hline Number of observations & 263854 & 263854 & 263854 & 263854 & 263854 & 175414 \\
\hline
\end{tabular}

Notes: Estimates are from two-stage least squares models with interactions between grade and category of television introduction year, and interactions between these variables and the full set of student demographics, used as instruments for years of television exposure and years of television exposure interacted with preschool reading frequency. Standard errors in parentheses are adjusted for clustering on DMA. All dependent measures are standardized to have a mean of zero and a standard deviation of unity within each grade. All specifications include fixed effects for school and grade, interactions between grade and $\log$ (DMA population) in 1960 and $\log$ (DMA total income) in 1959, controls for gender, English spoken at home, father's education, mother's education, race, lives with biological father, lives with biological mother, and separate dummies for whether student's family has a telephone, a record player, a refrigerator, a vacuum cleaner, or a car, and demographic controls interacted with grade dummies. Dummies are included to indicate missing values for demographic controls. General knowledge test scores are only available for students in grades 9 and 12 . 
Table 9 Effect of television exposure on social and behavioral outcomes

\begin{tabular}{lcc}
\hline \hline Dependent variable & $\begin{array}{c}\text { Effect of one year of } \\
\text { television exposure }\end{array}$ & $N$ \\
\hline Number of hours spent on homework each day & 0.0148 & 334719 \\
& $(0.0424)$ & \\
Number of books read during summer & -0.0760 & 336129 \\
(standardized) & $(0.0423)$ & \\
Number of hours spent watching television each day & -0.0211 & 335981 \\
(current) & $(0.0502)$ & \\
Student sometimes feels like (s)he "just can't learn" & -0.0040 & 327283 \\
& $(0.0208)$ & \\
Highest grade student wants to finish in school & -0.0265 & 333572 \\
(standardized) & $(0.0222)$ & \\
Share of membership organizations & 0.0170 & 217392 \\
\end{tabular}

Notes: Estimates are from two-stage least squares models with interactions between grade and category of television introduction year used as instruments for years of television exposure. Standard errors in parentheses are adjusted for clustering on DMA. Standardized measures have a mean of zero and a standard deviation of unity within each grade. Baseline includes fixed effects for school and grade and interactions between grade and $\log$ (DMA population) in 1960 and $\log$ (DMA total income) in 1959. All regressions include controls for gender, English spoken at home, father's education, mother's education, race, lives with biological father, lives with biological mother, and separate dummies for whether student's family has a telephone, a record player, a refrigerator, a vacuum cleaner, or a car, as well as for interactions between grade dummies and these controls. Dummies are included to indicate missing values for demographic controls. Share of membership organizations is number of the following organizations that the student belongs to, divided by the total number of organizations for which the student provides a response: sports team, Student Council, debate team, and hobby club. Participation in membership organizations is only available for students in grades 9 and 12 . 
Table 10 Effect of television exposure on labor market earnings and schooling attainment

\begin{tabular}{lcccc}
\hline \hline & $(1)$ & $(2)$ & $(3)$ & $(4)$ \\
$\begin{array}{l}\text { Dependent variable } \\
\text { Cohorts }\end{array}$ & Completed H.S. & $\log$ (wage income) & $\log ($ wage income) & $\log$ (wage income) \\
Sample & 1948, 1951, 1954 & $1948,1951,1954$ & $1948,1951,1954$ & $1930-1941$ \\
& All & All & $\begin{array}{c}\text { Prime-age } \\
\text { white males }\end{array}$ & $\begin{array}{c}\text { Prime-age } \\
\text { white males }\end{array}$ \\
\hline $\begin{array}{l}\text { Years of television } \\
\text { exposure, ages 2-6 }\end{array}$ & -0.0020 & -0.0371 & -0.0118 & \\
$\begin{array}{l}\text { Years of television } \\
\text { exposure, ages 7-18 }\end{array}$ & $(0.0135)$ & $(0.0397)$ & $(0.0396)$ & \\
\hline $\begin{array}{l}\text { Number of obs. } \\
\text { Number of states }\end{array}$ & 285650 & & & 0.0102 \\
\hline \hline
\end{tabular}

Notes: Data from Ruggles et al (2004). Estimates are from two-stage least squares models with interactions between birth year and category of television introduction year used as instruments for years of television exposure. Standard errors in parentheses are adjusted for clustering on state of birth. All specifications include fixed effects for state of birth, year, and year of birth, as well as dummies for year of birth interacted with $\log$ (state income) in 1959 and $\log$ (state population) in 1960. 
Figure 1 The diffusion of television, 1945 to 1970

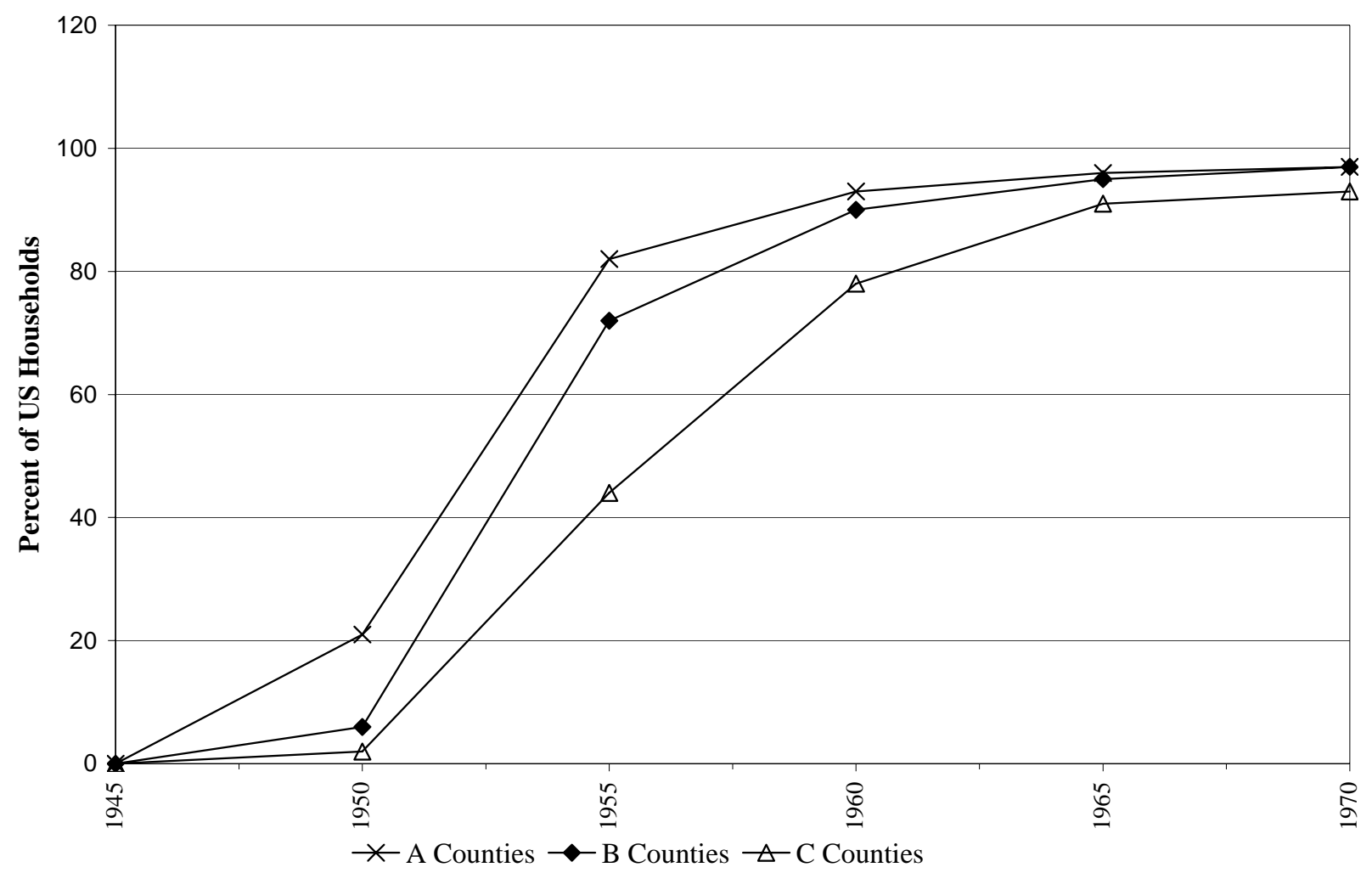

Source: Sterling (1984).

Notes: "A Counties" are all counties in the 25 largest metropolitan areas. "B Counties" are all counties not in A with populations of over 150,000 or in metropolitan areas over 150,000. "C Counties" are all others. 
Figure 2 The expansion of commercial television, 1940-1970

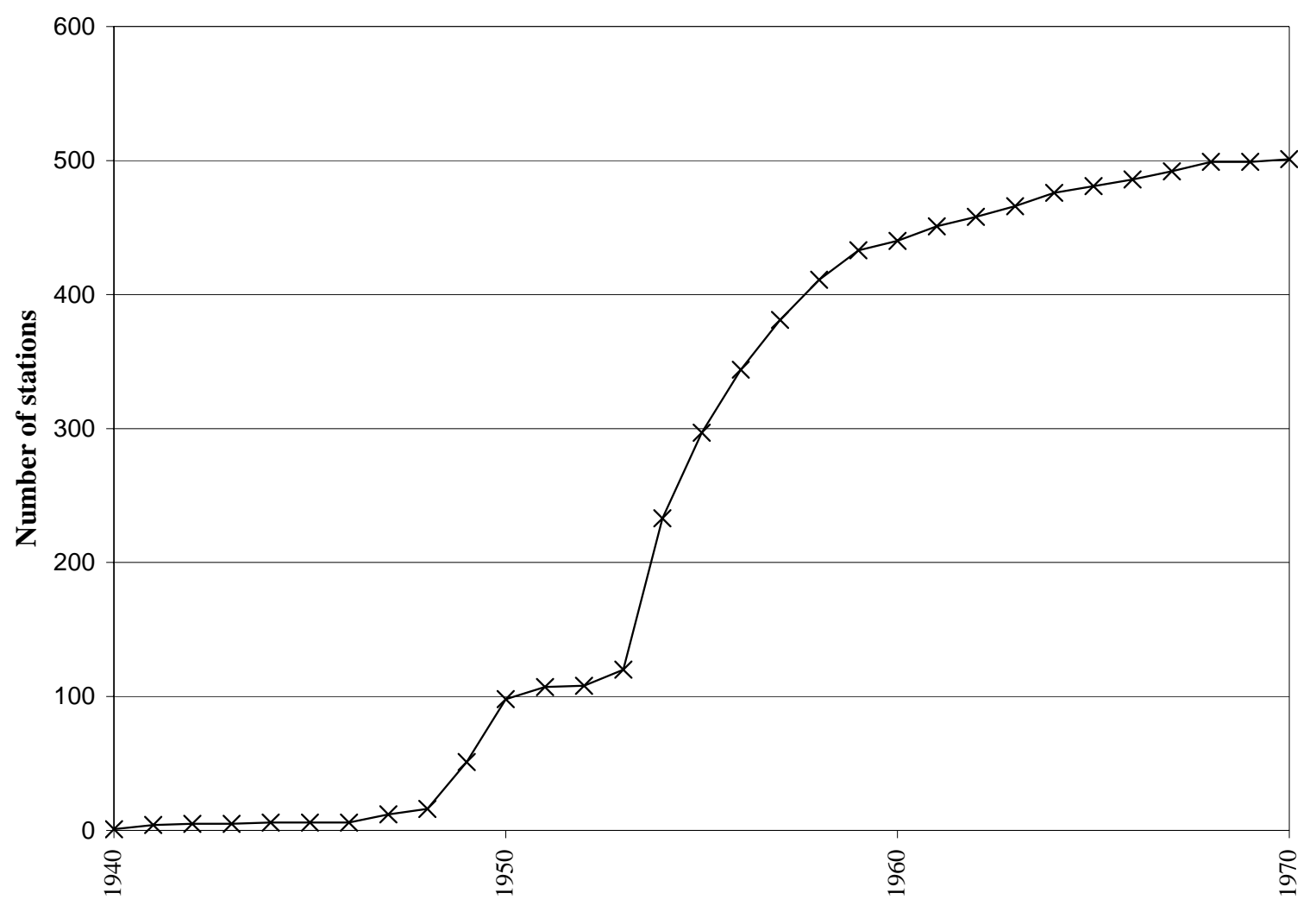

Source: Television Factbooks, various years. 
Figure 3 The diffusion of television by education level

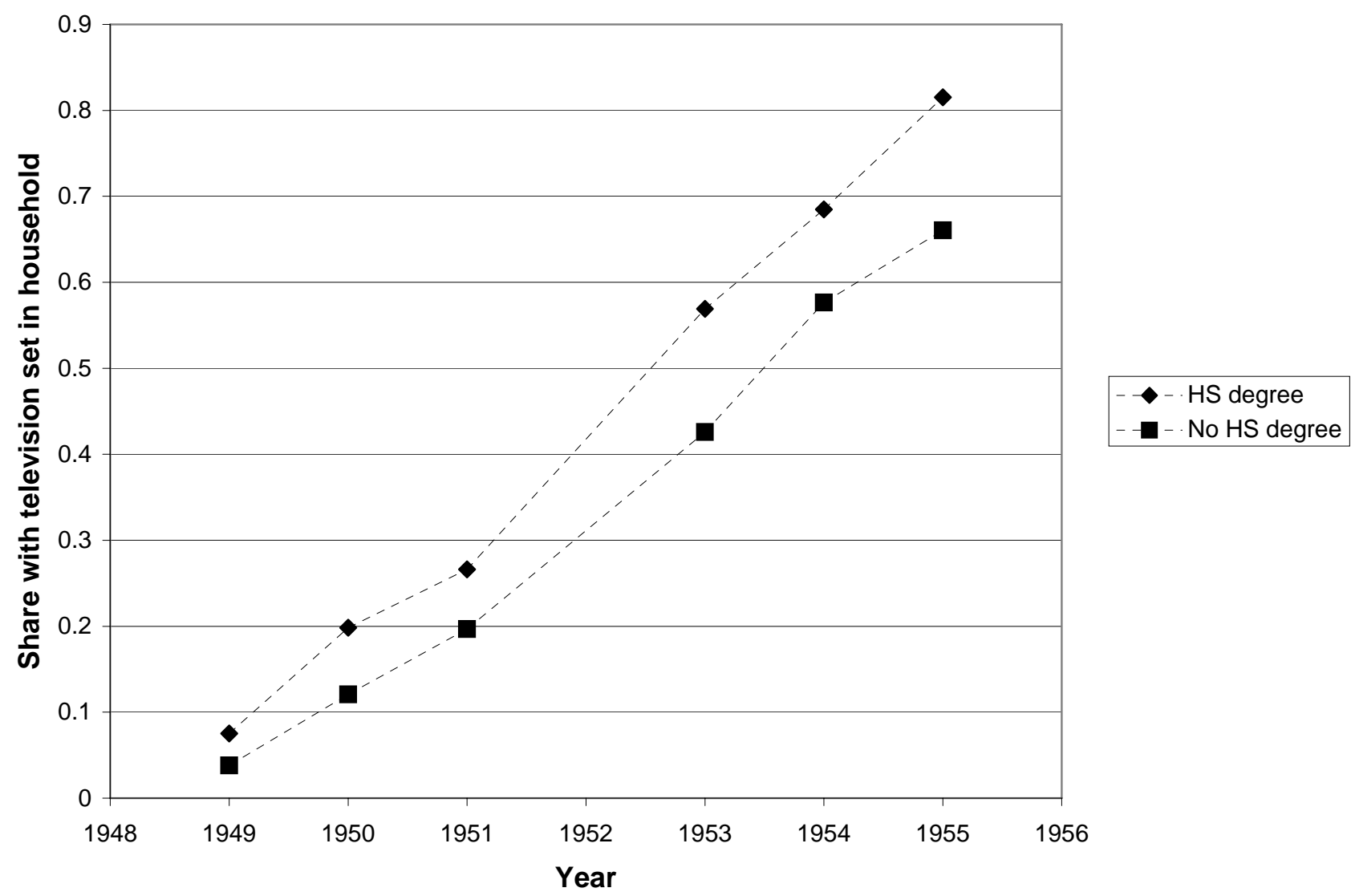

Notes: Data from nationally representative Gallup polls of American households (Roper Center for Public Opinion Research, 1949-1955). Figure shows the share of respondents who report having a television in their household by year, for respondents with and without a high-school degree. 
Figure 4 Television penetration in 1950 by year of TV introduction

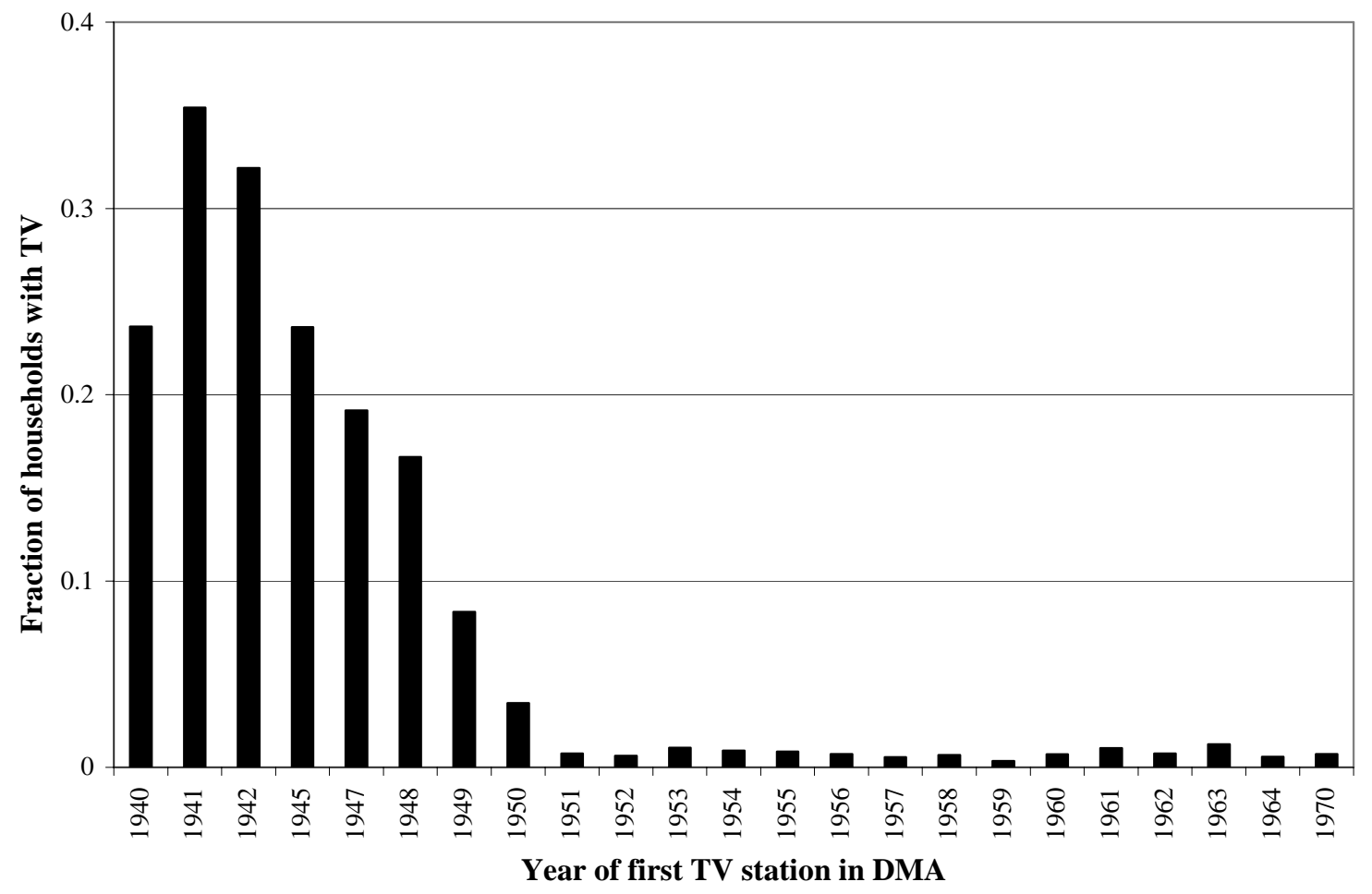

Source: Television Factbooks, various years.; 1950 U.S. Census.

Notes: The height of each bar is the fraction of households with television sets as recorded in the 1950 or 1960 census, averaged over all DMAs that received television in the given year. Years in which no county received their first station are omitted from the figure. 
Appendix Table 1 Is predicted television exposure correlated with observables?

\begin{tabular}{|c|c|c|}
\hline & $\begin{array}{c}\text { Predicted years of television } \\
\text { exposure } \\
(1)\end{array}$ & $\begin{array}{c}\text { Standardized average } \\
\text { test score } \\
(2)\end{array}$ \\
\hline Male & $\begin{array}{c}-0.4730 \\
(0.6152)\end{array}$ & $\begin{array}{c}-0.0524 \\
(0.0066)\end{array}$ \\
\hline $\begin{array}{l}\text { English not spoken } \\
\text { at home }\end{array}$ & $\begin{array}{c}0.6050 \\
(0.6701)\end{array}$ & $\begin{array}{l}-0.1798 \\
(0.0079)\end{array}$ \\
\hline $\begin{array}{l}\text { Father's education } \\
\text { (index) }\end{array}$ & $\begin{array}{l}-0.1875 \\
(0.1887)\end{array}$ & $\begin{array}{c}0.0544 \\
(0.0016)\end{array}$ \\
\hline $\begin{array}{l}\text { Mother's education } \\
\text { (index) }\end{array}$ & $\begin{array}{l}-0.0205 \\
(0.2259)\end{array}$ & $\begin{array}{c}0.0481 \\
(0.0015)\end{array}$ \\
\hline White & $\begin{array}{c}0.2699 \\
(0.4412)\end{array}$ & $\begin{array}{c}0.3858 \\
(0.0294)\end{array}$ \\
\hline $\begin{array}{l}\text { Lives with } \\
\text { biological father }\end{array}$ & $\begin{array}{l}-0.8221 \\
(0.9202)\end{array}$ & $\begin{array}{c}0.0757 \\
(0.0057)\end{array}$ \\
\hline $\begin{array}{l}\text { Lives with } \\
\text { biological mother }\end{array}$ & $\begin{array}{l}-0.0244 \\
(1.2240)\end{array}$ & $\begin{array}{c}0.1762 \\
(0.0059)\end{array}$ \\
\hline \multicolumn{3}{|l|}{ Family has } \\
\hline Telephone & $\begin{array}{c}0.9153 \\
(1.0186)\end{array}$ & $\begin{array}{c}0.1069 \\
(0.0079)\end{array}$ \\
\hline Record player & $\begin{array}{l}-0.4899 \\
(0.8809)\end{array}$ & $\begin{array}{c}0.0226 \\
(0.0044)\end{array}$ \\
\hline Refrigerator & $\begin{array}{c}0.0589 \\
(1.1307)\end{array}$ & $\begin{array}{c}0.4070 \\
(0.0143)\end{array}$ \\
\hline Vacuum & $\begin{array}{l}-0.1219 \\
(0.6499)\end{array}$ & $\begin{array}{c}0.0610 \\
(0.0092)\end{array}$ \\
\hline Car & $\begin{array}{c}1.3549 \\
(0.7150)\end{array}$ & $\begin{array}{c}0.0607 \\
(0.0093)\end{array}$ \\
\hline$F(12,135)$ & 1.09 & 708.12 \\
\hline$(p-$ value $)$ & $(0.3712)$ & $(<0.0001)$ \\
\hline Number of observations & 404 & 346562 \\
\hline Number of schools & - & 800 \\
\hline Number of DMAs & 136 & 136 \\
\hline
\end{tabular}

Notes: Standard errors in parentheses are adjusted for clustering on DMA. Average test score is standardized to have a mean of zero and a standard deviation of unity within each grade. All regressions include fixed effects for grade and interactions between grade and $\log$ (DMA population) in 1960 and $\log$ (DMA total income) in 1959. Regression (1) includes fixed effects for DMA; regression (2) includes fixed effects for school. Dummies are included to indicate missing values for demographic controls. 
Appendix Table 2 Is predicted television exposure correlated with teacher characteristics?

\begin{tabular}{lc}
\hline \hline & $\begin{array}{c}\text { Predicted years of television } \\
\text { exposure }\end{array}$ \\
\hline Male & -0.2581 \\
& $(0.4885)$ \\
White & 0.3625 \\
& $(0.3528)$ \\
Age & 0.0074 \\
& $(0.0212)$ \\
Father's education & -0.0192 \\
(index) & $(0.0924)$ \\
Mother's education & -0.0434 \\
(index) & $(0.1122)$ \\
Has Master's degree & 0.1907 \\
& $(0.4489)$ \\
Years of classroom & -0.0296 \\
experience & $(0.0267)$ \\
Salary (\$1000) & 0.1601 \\
Hours per day spent & $(0.1313)$ \\
in classroom & -0.1400 \\
Class size & $(0.1566)$ \\
Number of different & -0.0037 \\
Nubjects taught & $(0.0178)$ \\
\hline \hline & 0.1293 \\
Number test score & $(0.0621)$ \\
\hline
\end{tabular}

Notes: Standard errors in parentheses are adjusted for clustering on DMA. Average test score is standardized to have a mean of zero and a standard deviation of unity within each grade. All regressions include fixed effects for grade and DMA and interactions between grade and $\log$ (DMA population) in 1960 and $\log$ (DMA total income) in 1959. Dummies are included to indicate missing values for demographic controls. 
Appendix Table 3 Is television introduction correlated with trends in school quality?

\begin{tabular}{lc}
\hline \hline & Year state first received television \\
\hline Change in log(average relative teacher salary): & \\
1920 cohort - 1930 cohort & $(4.1332)$ \\
& -0.0906 \\
1930 cohort - 1940 cohort & $(6.3179)$ \\
& \\
Change in $\log$ (average number of school days per year): & \\
1920 cohort - 1930 cohort & -18.2696 \\
& $(14.0157)$ \\
1930 cohort -1940 cohort & 40.8373 \\
& $(26.3258)$ \\
Change in $\log ($ average teacher-student ratio): & \\
1920 cohort -1930 cohort & -1.6722 \\
1930 cohort - 1940 cohort & $(5.2949)$ \\
& 8.9435 \\
$F(6,39)$ & $(6.5421)$ \\
$p-$ value & 48 \\
\hline \hline
\end{tabular}

Notes: Unit of observation is the U.S. state (excluding Alaska and Hawaii). Dependent variable is the first year in which any county in the state could receive a television broadcast. Independent variables are taken from Card and Krueger (1992), as coded by Christopher Berry (2004). 
Appendix Table 4 Sample splits by place of residence in childhood

\begin{tabular}{lcccccc}
\hline \hline & $\begin{array}{c}\text { Standardized } \\
\text { average } \\
\text { test score }\end{array}$ & Math & $\begin{array}{c}\text { Standardized component: } \\
\text { Spatial } \\
\text { reasoning }\end{array}$ & Verbal & Reading & $\begin{array}{c}\text { General } \\
\text { knowledge }\end{array}$ \\
\hline Students who report spending most of their lives in this town or elsewhere in state: & \\
Years of preschool & 0.0227 & -0.0239 & 0.0022 & 0.0347 & 0.0578 & 0.0497 \\
television exposure & $(0.0278)$ & $(0.0391)$ & $(0.0402)$ & $(0.0266)$ & $(0.0294)$ & $(0.0422)$ \\
Number of observations & 288828 & 288828 & 288828 & 288828 & 288828 & 199494 \\
Number of schools & 800 & 800 & 800 & 800 & 800 & 705 \\
Number of DMAs & 136 & 136 & 136 & 136 & 136 & 134 \\
& & & & & & \\
Students who report spending most of their lives in another state or country: & & & \\
Years of preschool & -0.0124 & -0.0461 & -0.0222 & -0.0062 & 0.0233 & 0.0618 \\
television exposure & $(0.0524)$ & $(0.0567)$ & $(0.0464)$ & $(0.0648)$ & $(0.0508)$ & $(0.1192)$ \\
Number of observations & 50807 & 50807 & 50807 & 50807 & 50807 & 22816 \\
Number of schools & 800 & 800 & 800 & 800 & 800 & 671 \\
Number of DMAs & 136 & 136 & 136 & 136 & 136 & 133 \\
\hline \hline
\end{tabular}

Notes: Estimates are from two-stage least squares models with interactions between grade and category of television introduction year used as instruments for years of television exposure. Standard errors in parentheses are adjusted for clustering on DMA. All dependent measures are standardized to have a mean of zero and a standard deviation of unity within each grade. All specifications include fixed effects for school and grade, interactions between grade and $\log$ (DMA population) in 1960 and $\log$ (DMA total income) in 1959, controls for gender, English spoken at home, father's education, mother's education, race, lives with biological father, lives with biological mother, and separate dummies for whether student's family has a telephone, a record player, a refrigerator, a vacuum cleaner, or a car, and demographic controls interacted with grade dummies. Dummies are included to indicate missing values for demographic controls. General knowledge test scores are only available for students in grades 9 and 12 . 
Appendix Table 5 The top five children's television programs, 1953 and 2003

\begin{tabular}{lcc}
\hline \hline Rank & Top Shows, 1953 & Top Shows, 2003 \\
\hline 1 & $\begin{array}{c}\text { I Love Lucy } \\
\text { (comedy) }\end{array}$ & $\begin{array}{c}\text { The Simpsons } \\
\text { (animated comedy) }\end{array}$ \\
2 & $\begin{array}{c}\text { Superman } \\
\text { (action) }\end{array}$ & $\begin{array}{c}\text { American Idol } \\
\text { (game show) }\end{array}$ \\
4 & $\begin{array}{c}\text { The Red Buttons Show } \\
\text { (comedy/variety) }\end{array}$ & $\begin{array}{c}\text { Malcolm in the Middle } \\
\text { (situation comedy) }\end{array}$ \\
5 & $\begin{array}{c}\text { Dragnet } \\
\text { (police drama) }\end{array}$ & $\begin{array}{c}\text { Fear Factor } \\
\text { (game show) }\end{array}$ \\
& The Roy Rogers Show & Survivor: Amazon \\
(western) & (reality show) \\
\hline \hline
\end{tabular}

Notes: Data on 1953 viewing patterns are from a survey of elementary pupils' "favorite" programs reported in Television, April 1955, p. 84. Data on 2003 viewing patterns are from Nielsen audience data for children ages 2-11. 